\title{
Sistem Pengecekan Status Dokumen Jemaah Umroh Pada PT. Solusi Balad Lumampah Cabang Jakarta Berbasis Web
}

\author{
Octa Rizky S. ${ }^{1)}$, Mira Ziveria ${ }^{2)}$ \\ Sistem Informasi, Institut Teknologi dan Bisnis Kalbis \\ Jalan Pulomas Selatan Kav. 22, Jakarta 13210 \\ ${ }^{1)}$ Email: projectfmcxx@gmail.com \\ ${ }^{2)}$ Email:miraziveria@kalbis.ac.id
}

\begin{abstract}
Currently many Muslims are traveling to perform the pilgrimage and umroh. It is also supported by one of the religious obligations of Islam that ordered the followers to perform the pilgrimage and umrah for the capable. But to be able to travel hajj or umroh is required for to have some supporting documents. Related documents supporting the pilgrims and umroh journey if prospective pilgrims have lack of supporting documents, the administration of PT. Balad Lumampah solution will contact prospective congregation by phone or SMS which is considered very inefficient. The purpose of this research is to build a system of checking the status of pilgrim document by using website at PT. Balad Lumampah Solution. The method used for system development is Prototyping and built with PHP programming language. The result of this system is facilitate prospective congregation in knowing the development of supporting documents being processed.
\end{abstract}

Keywords: Document Checking, PHP, Prototyping, Website

\begin{abstract}
Asbtrak: Saat ini banyak umat Islam yang bepergian untuk melaksanakan ibadah haji maupun umroh. Hal tersebut juga didukung oleh salah satu kewajiban agama Islam yang memerintahkan pemeluknya untuk melakukan ibadah haji dan umrah bagi yang mampu. Tetapi untuk dapat melakukan perjalanan haji ataupun umroh diperlukan bagi calon jemaah untuk memiliki beberapa dokumen pendukung. Terkait dokumen pendukung perjalanan haji maupun umroh tersebut apabila calon jemaah memiliki kekurangan dokumen pendukung, pihak administrasi PT. Solusi Balad Lumampah akan menghubungi calon jemaah melalui telepon atau SMS yang dirasa sangat tidak efesien karena harus mengeluarkan biaya tambahan untuk menghubungi calon jemaah. Tujuan dari penelitian ini adalah untuk membangun sistem pengecekan status dokumen jemaah dengan menggunakan website pada PT. Solusi Balad Lumampah. Metode yang digunakan untuk pengembangan sistem adalah Prototyping dan dibangun dengan bahasa pemrograman PHP. Hasil dari sistem ini adalah memudahkan calon jemaah dalam mengetahui perkembangan dokumen pendukung yang sedang diproses.
\end{abstract}

Kata kunci: pengecekan dokumen, PHP, prototyping, website

\section{PENDAHULUAN}

Saat ini banyak umat Islam yang bepergian untuk melaksanakan ibadah haji maupun umroh. Hal tersebut juga didukung oleh salah satu kewajiban agama Islam yang memerintahkan pemeluknya untuk melakukan ibadah haji dan umrah bagi yang mampu.

Demi mendapatkan calon jemaah haji maupun umroh yang banyak selain melakukan promosi yang masif baik online maupun offline, biro perjalanan wisata melakukan berbagai macam strategi seperti membuat harga tiket menjadi murah, memberikan fasilitas yang lebih dari harga yang diberikan, hingga memasang iklan secara masif. Tetapi untuk dapat melakukan perjalanan haji ataupun umroh diperlukan bagi calon jemaah untuk memiliki beberapa dokumen pendukung, seperti passport, visa, maupun bukti vaksinasi berupa kartu kuning yang berbentuk sertifikat yang menunjukan bahwa calon jemaah haji ataupun umroh telah divaksinasi terhindar dari penyakit yang mungkin menjangkiti mereka. Dalam penelitian ini penulis menjadikan PT. Solusi Balad Lumampah sebagai objek penelitian. PT. Solusi Balad Lumampah didirikan pada tahun 2011, terletak di Wisma Bumi Putera lantai 5 dan 9, jalan Asia Afrika No.141-149, Bandung, Jawa Barat. PT. Solusi Balad Lumampah merupakan perusahaan jasa tours dan travel selaku pemegang izin Penyelenggaraan 
Perjalanan Umroh dan Haji Plus dan izin resmi Kemenag RI No. 561 tahun 2016 [1].

Dalam proses pendaftaran jemaah baik jemaah haji maupun jemaah umroh, PT. Solusi Balad Lumampah membutuhkan dokumen pendukung milik calon jemaah berupa pas foto, passport, dan sertifikat vaksinasi; yang kemudian dibutuhkan untuk membuat visa umroh. Dalam proses yang berjalan saat ini apabila calon jemaah memiliki kekurangan dokumen pendukung, pihak administrasi PT. Solusi Balad Lumampah akan menghubungi calon jemaah melalui telepon maupun SMS yang dirasa sangat tidak efesien karena harus mengeluarkan biaya tambahan untuk menghubungi calon jemaah terlebih apabila dokumen yang dibutuhkan lebih dari satu dan munculnya tidak bersamaan.

Berdasarkan pengamatan yang peneliti lakukan dalam membantu memecahkan masalah yang dihadapi oleh PT. Solusi Balad Lumampah, maka diperlukan untuk membuat suatu website yang menampung segala informasi tentang dokumen yang dibutuhkan oleh calon jemaah, baik itu dokumen yang belum lengkap, maupun perkembangan dokumen yang sedang dalam proses.

Penyelenggara perjalanan ibadah haji adalah rangkaian kegiatan pengelolaan pelaksanaan ibadah haji yang meliputi pembinaan, pelayanan, dan perlindungan jemaah haji [2]. Sedangkan penyelenggara perjalanan ibadah umroh adalah rangkaian kegiatan perjalanan ibadah umroh yang meliputi pembinaan, pelayanan, dan perlingungan jemaah umroh, yang dilaksanakan oleh pemerintah dan atau penyelenggara perjalanan ibadah umroh [3].

Untuk melaksanakan penelitian ini, peneliti menggunakan metode pengembangan sistem prototyping dikarenakan metode ini hanya membutuhkan beberapa kebutuhan umum perangkat lunak tanpa detil input, proses atau detil output. Ketika situasi seperti ini terjadi metode pengembangan sistem prototyping sangat membantu proses pembangunan perangkat lunak [4]. Berdasarkan latar belakang masalah yang dihadapi oleh PT. Solusi Balad Lumampah, maka rumusan masalahnya adalah bagaimana membangun sebuah sistem pengecekan status dokumen jemaah pada PT. Solusi Balad Lumampah berbasis website.

\section{METODE PENELITIAN}

\section{A. Penelitian Terdahulu}

Penelitian ini melibatkan dua penelitian terdahulu, yaitu yang pertama adalah penelitian yang dilakukan oleh Dony Saputra, Siswanto, dan Fery Susanto pada tahun 2014 didalam jurnal yang berjudul "Perancangan Sistem Tracking Report Process Production Pada PT. Indotaichen Textile Industry" memaparkan bahwa sistem tracking report/pengecekan status mengandalkan penggunaan barcode [5]. Sedangkan penelitian yang kedua adalah penelitian yang dilakukan oleh Muhammad Yopi Ramadhan Siregar, dan Fajrillah pada tahun 2016 yang berjudul "Pengembangan Sistem Pengelolaan Publikasi Dokumen Mahasiswa STTH Medan Berbasis Cloud Computing" memaparkan bahwa publikasi dokumen yang dimiliki oleh STTH Medan masih manual [6].

Tujuan dari jurnal penelitian yang pertama adalah "Menemukan faktor utama yang menyebabkan lead time proses produksi yang masih seringkali melampaui standar waktu yang telah ditetapkan dan mencari solusi alternatifnya. Sedangkan tujuan dari jurnal penelitian yang kedua adalah "Membantu menyajikan informasi dimana mahasiswa dapat mencari referensi dan panduan dalam masa perkulihan seperti membuat tugas dan jurnal dengan mudah, cepat dan efisien tanpa harus mengunjungi perpustakaan ataupun melalui kantor jurusan terlebih dahulu untuk mendapatkannya".

Kedua jurnal penelitian tersebut memiliki kontribusi yang berbeda-beda, seperti misalnya jurnal yang berjudul "Perancangan Sistem Tracking Report Process Production Pada PT. Indotaichen Textile Industry" berkontribusi terhadap metode pengembangan sistem, sedangkan jurnal yang berjudul "Pengembangan Sistem Pengelolaan Publikasi Dokumen Mahasiswa STTH Medan Berbasis Cloud Computing" berkontribusi terhadap metode pengembangan sistem, dan masalah yang dihadapi memiliki keterkaitan.

\section{B. Kerangka Berpikir}

Kerangka berpikir dari penelitian ini dapat dilahat pada Gambar 1.

Penjelasan Gambar 1 adalah sebagai berikut: 1) Studi Literatur. Pada tahap ini peneliti membaca jurnal, buku, dan artikel di internet guna memahami studi literatur yang akan peneliti gunakan; 2). Observasi dan Wawancara: a) Peneliti melakukan observasi pada proses pengajuan dokumen yang terjadi pada PT. Solusi Balad Lumampah Cabang Jakarta; dan b) Peneliti melakukan wawancara dengan narasumber Bapak Dwi Saptono selaku Kepala Cabang PT. Solusi Balad Lumampah Cabang Jakarta; 3) Identifikasi: a) Peneliti melakukan identifikasi terhadap masalah 


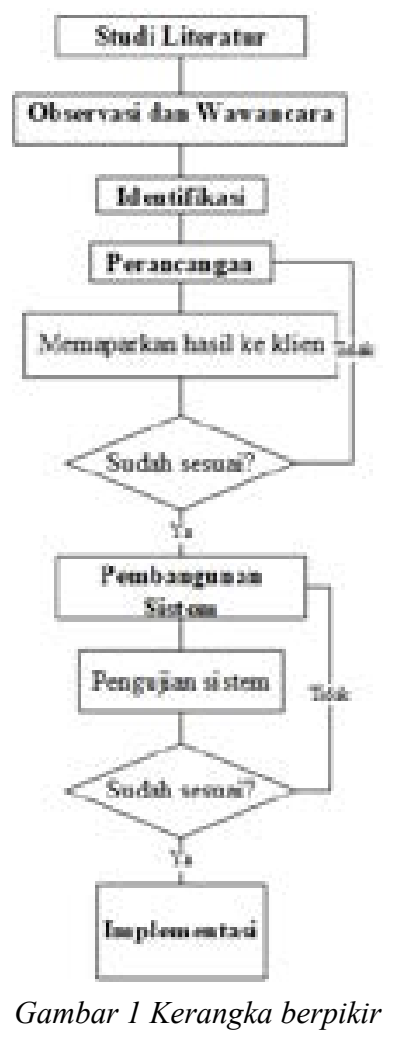

yang dihadapi, dan tujuan dari pembuatan sistem yang nanti akan dibangun; b) Peneliti melakukan pengumpulan data dengan menggunakan metode observasi dan wawancara; dan c) Setelah selesai melakukan pengumpulan data, peneliti melakukan analisa terhadap kebutuhan sistem berdasarkan data yang telah terkumpul; 4) Perancangan. Pada tahapan ini, penulis membuat rancangan sistem, basis data, dan tampilan antar muka sistem dengan menggunakan: a) Rancangan desain alur sistem menggunakan use case diagram, activity diagram, dan sequence diagram; b) Untuk rancangan basis data peneliti menggunakan entity relationship diagram, dan class diagram; dan c) Balsamiq Mockups untuk rancangan tampilan antar muka. Apabila rancangan sudah sesuai dan disetujui oleh klien, maka dilanjut ke tahap berikutnya. Apabila belum sesuai maka akan kembali dirancang sampai sesuai dengan keinginan dan kebutuhan klien; dan 5) Pembangunan Sistem: a). Peneliti membuat realisasi dari rancangan basis data, dan membangun sistem dengan menggunakan PHP, HTML, CSS, dan Bootstrap; dan b) Sistem akan diuji dengan menggunakan metode pengujian black box. Apabila belum sesuai maka akan kembali dibangun dan diuji sampai sistem sesuai dengan keinginan dan kebutuhan klien untuk kemudian diimplementasikan.

\section{HASIL DAN PEMBAHASAN}

Pada bagian ini, peneliti menjelaskan profil perusahaan, visi-misi perusahaan, struktur organisasi, analisis sistem yang sedang berjalan, kelemahan sistem yang berjalan, analisis kebutuhan, analisis sistem usulan, perancangan sistem, perancangan basisdata, perancangan antarmuka, skenario pengujian, dan hasil pembangunan sistem.

\section{A. Profil Perusahaan}

PT. Solusi Balad Lumampah didirikan pada tahun 2011 di Bandung, yang dipelopori oleh Bapak H. Aom Juang Wibowo SN, Bapak H. Eri Ramdani dan Bapak H. Ronnie Kustiawan, S.Pd.merupakan perusahaan jasa tours\&travel selaku pemegang izin Penyelenggaraan Perjalanan Umroh dan Haji Plus yang bertempat di Wisma Bumiputera yang terletak di Jalan Asia Afrika no.141-149 Bandung, Jawa Barat. PT. Solusi Balad Lumampah juga merupakan perusahaan provider dibidang umrah dan haji plus.

\section{B. Analisis Sistem Yang Sedang Berjalan}

Analisis sistem yang sedang berjalan adalah kegiatan menganalisis aktifitas yang terjadi pada sistem yang berjalan. Analisis sistem yang sedang berjalan pada PT. Solusi Balad Lumampah dapat dilihat pada Gambar 3.

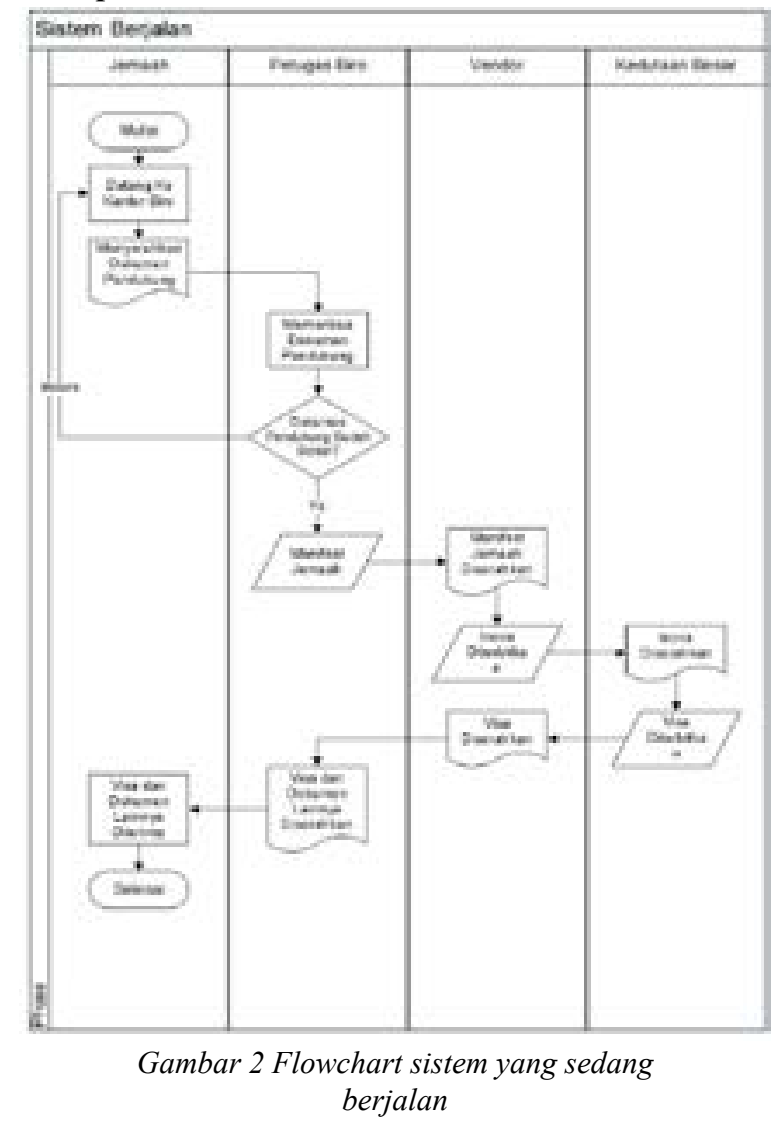

Penjelasan terhadap flowchart sistem yang sedang berjalan yang digambarkan pada Gambar 2 yaitu: 1) Jemaah datang ke kantor biro; 2) Jemaah menyerahkan dokumen pendukung ke petugas biro. dokumen pendukung berupa: Paspor asli dengan nama 
tiga kata, dan masih berlaku minimal 8 bulan setelah keberangkatan; Fotokopi kartu keluarga dan kartu tanda penduduk; Surat nikah asli (bagi suami istri); Akte kelahiran asli (bagi yang membawa anak); Pas foto terbaru berwarna dengan background putih dan close up wajah 80\%. ukuran 4x6 sebanyak 5 lembar, dan ukuran $3 \times 4$ sebanyak 2 lembar; Kartu kuning vaksin meningitis asli; 3) Petugas biro memeriksa dokumen pendukung milik jemaah selama 7 hari (5 hari kerja); 4) Apabila dokumen benar maka petugas biro akan membuat manifest jemaah dan menyerahkan manifest tersebut ke pihak vendor untuk kemudian dibuatkan dokumen bernama inova untuk diteruskan ke kedutaan besar untuk proses visa; 5) Setelah visa terbit dari kedutaan besar, visa diserahkan kepada vendor, dan vendor menyerahkan visa ke pihak biro; 6) Visa diserahkan oleh pihak biro bersama dokumen pendukung lainnya milik Jemaah sesaat sebelum keberangkatan di bandara; dan 7) Apabila dokumen ada yang salah atau kurang atau kadaluarsa, maka petugas biro akan menghubungi jemaah untuk mengembalikan dokumen milik Jemaah selama 2 hari kerja untuk kemudian dokumen tersebut diserahkan kembali ke petugas biro sampai benar

\section{E. Kelemahan Sistem Yang Berjalan}

Berdasarkan hasil analisa yang peneliti lakukan pada sistem yang sedang berjalan ditemukan beberapa kelemahan dari sistem yang berjalan, diantaranya: 1) Terjadinya penumpukan fisik dokumen pendukung milik jemaah, ini dikarenakan satu Jemaah memiliki fisik dokumen pendukung yang banyak dan berpotensi mengalami kehilangan dokumen maupun tumpang tindih dengan dokumen milik jemaah lain; 2) Proses pemeriksaan dokumen yang lama karena dokumen yang diperiksa berbentuk dokumen fisik, yaitu selama 7 hari / efektif 5 hari kerja; 3) Proses pengembalian dokumen ke Jemaah yang cukup memakan waktu, yaitu 2 hari kerja; dan 4) Jemaah harus datang lagi ke kantor biro untuk menyerahkan dokumen mereka ke pihak biro untuk dilakukan proses pengecekan kembali.

\section{F. Analisis Kebutuhan}

Penelitian ini menggunakan analisis kebutuhan yang digunakan dalam membangun sistem ini. Analisis kebutuhan yang digunakan dalam membangun aplikasi ini ada dua (2), yaitu analisis kebutuhan fungsional dan non-fungsional.

1. Analisis Kebutuhan Fungsional. Kebutuhan fungsional adalah kebutuhan yang terkait dengan kebutuhan sistem. Kebutuhan fungsional dari sistem ini meliputi data admin, dan data jemaah. Data kebutuhan fungsional dari sistem ini dapat dilihat pada Tabel 1.

\section{Tabel 1 Kebutuhan fungsional}

\begin{tabular}{|l|l|}
\hline User & Kebutuhan \\
\hline Petugas & 1. Melakukan login \\
Biro & $\begin{array}{l}\text { 2. Melakukan registrasi akun Jemaah, } \\
\text { update status dokumen Jemaah, update } \\
\text { status keberangkatan Jemaah, melihat data } \\
\text { keseluruhan Jemaah, melihat data } \\
\text { rekapitulasi dokumen jemaah } \\
\text { 3. Melakukan logout }\end{array}$ \\
\hline Jemaah & $\begin{array}{l}\text { 1. Melakukan login } \\
\text { 2.Melihat profil akun Jemaah, } \\
\text { mengupload dokumen keberangkatan, } \\
\text { melihat status dokumen yang sudah } \\
\text { diupload } \\
\text { 3. Melakukan logout }\end{array}$ \\
\hline
\end{tabular}

2. Analisis Kebutuhan Non-Fungsional. Kebutuhan non-fungsional adalah kebutuhan yang tidak terkait dengan kebutuhan sistem. Kebutuhan non-fungsional terbagi menjadi dua, yaitu kebutuhan perangkat keras, dan kebutuhan perangkat lunak.

\section{G. Analisis Sistem Usulan}

Analisis sistem usulan adalah aktivitas menganalisa kegiatan-kegiatan yang dimiliki oleh sistem yang diusulkan. Fungsi utama dari Sistem Pengecekan Status Dokumen Jemaah Umroh Pada PT. Solusi Balad Lumampah Cabang Jakarta Berbasis Web yaitu: 1) Memudahkan Jemaah dalam melakukan pengajuan dokumen, dan mengetahui status dokumen yang sedang diajukan untuk keperluan bepergian ibadah haji maupun umroh; 2) Memudahkan petugas biro dalam memberitahukan status dokumen jemaah kepada jemaah itu sendiri; 3) Adanya daftar dan status penerbangan yang dimiliki oleh setiap jemaah; 4) Adanya data rekapitulasi dokumen yang telah diupload oleh jemaah; 5) Penggunaan database sebagai media penyimpanan dalam sistem ini; dan 6) Penggunaan web untuk memudahkan Jemaah dalam melakukan pengajuan dokumen, dan mengetahui status dokumen yang sedang diajukan.

1. Skenario Gambaran Sistem Usulan. Gambaran sistem usulan digambarkan berdasarkan aktifitas yang dapat dilakukan oleh user dari sistem ini, yaitu registrasi akun jemaah, pengajuan dokumen, pergantian password, update status dokumen, update keberangkatan:

a) Registrasi Akun Jemaah.

Adapun aktifitas yang terdapat pada proses registrasi akun jemaah dapat dilihat pada Gambar 3. Penjelasan dari alur sistem baru pada proses registrasi 


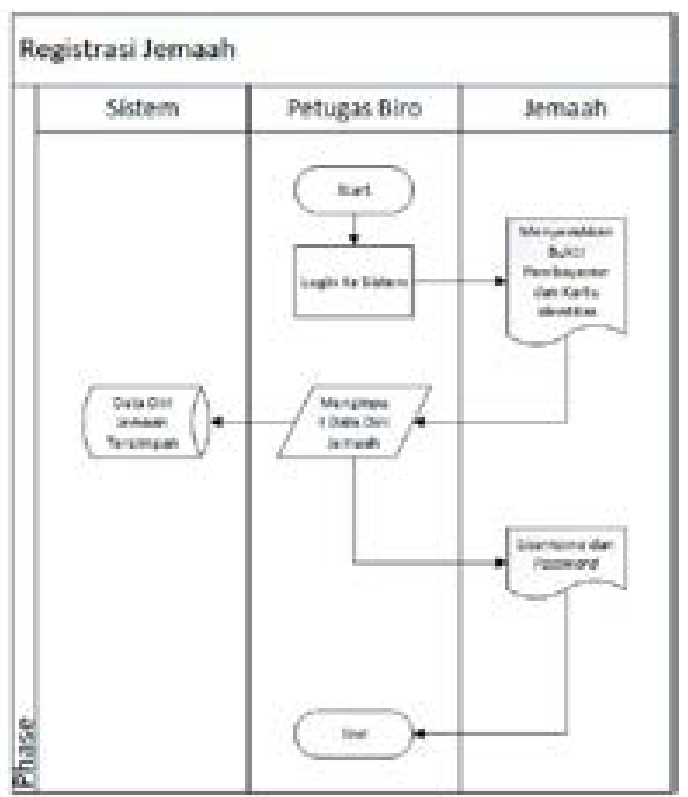

Gambar 3 Flowchart registrasi akun jemaah

akun jemaah seperti yang digambarkan pada Gambar 3 yaitu: 1) Petugas biro login ke dalam website; 2) Jemaah menyerahkan bukti pembayaran dan kartu identitas agar diregistrasi oleh petugas biro. Kartu identitas berupa Kartu Tanda Penduduk (KTP); 3) Petugas biro melakukan registrasi akun jemaah dengan menginput data diri jemaah kedalam website. Jemaah dapat menentukan sendiri username dan password. Data yang diinput tersimpan kedalam basisdata; dan 4) Setelah proses registrasi berhasil, petugas biro akan memberitahukan username dan password akun jemaah tersebut. Password yang diberikan akan dapat diganti oleh jemaah nanti apabila sudah login kedalam sistem.

b). Pengajuan Dokumen.

Adapun aktifitas yang terdapat pada proses pengajuan dokumen dapat dilihat pada flowchart yang terdapat pada Gambar 5. Penjelasan dari alur sistem

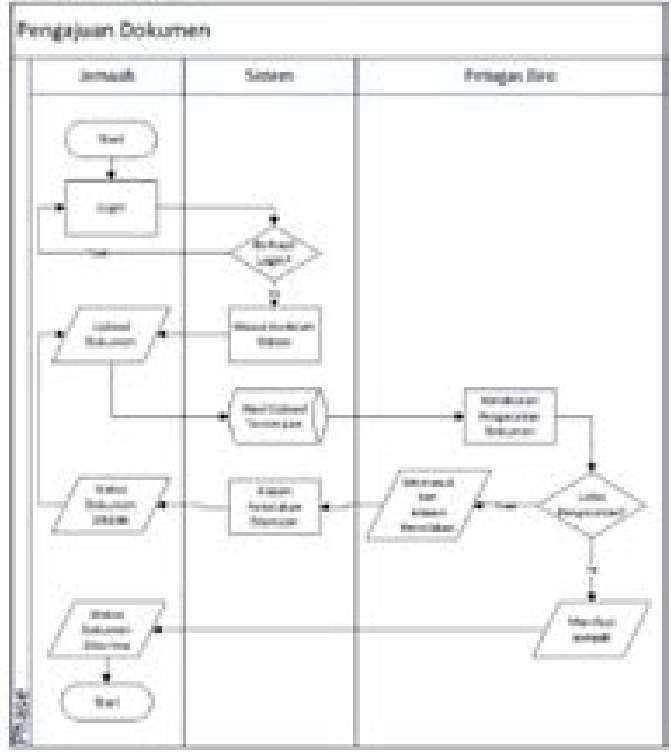

Gambar 4 Flowchart pengajuan dokumen baru pada proses pengajuan dokumen seperti yang digambarkan pada Gambar 4 yaitu: 1) Jemaah login ke dalam website; 2) Apabila jemaah gagal login yang disebabkan oleh kesalahan menginput password atau email, maka jemaah diharuskan untuk melakukan proses login ulang; 3) Setelah sukses login, jemaah masuk kedalam sistem, dan mengupload dokumen pendukung ke dalam sistem. Dokumen yang diupload berupa hasil scan dari tujuh dokumen pendukung dan dokumen asli yang diperlukan; 4) Setelah jemaah selesai mengupload dokumen, hasil upload akan tersimpan kedalam basisdata dan akan diperiksa oleh petugas biro; 5) Apabila lolos pengecekan, maka data yang ada di dokumen tersebut akan dimasukkan kedalam manifest oleh petugas biro dan petugas biro akan mengupdate status dokumen menjadi diterima; dan 6) Apabila tidak lolos pengecekan, maka petugas biro akan memasukkan alasan penolakan dokumen dan mengupdate status dokumen menjadi ditolak dan jemaah harus mengupload kembali hingga dokumen tersebut diterima.

\section{c. Kelengkapan Dokumen}

Adapun aktifitas yang terdapat pada proses pemeriksaan kelengkapan dokumen dapat dilihat pada flowchart yang terdapat pada Gambar 6.

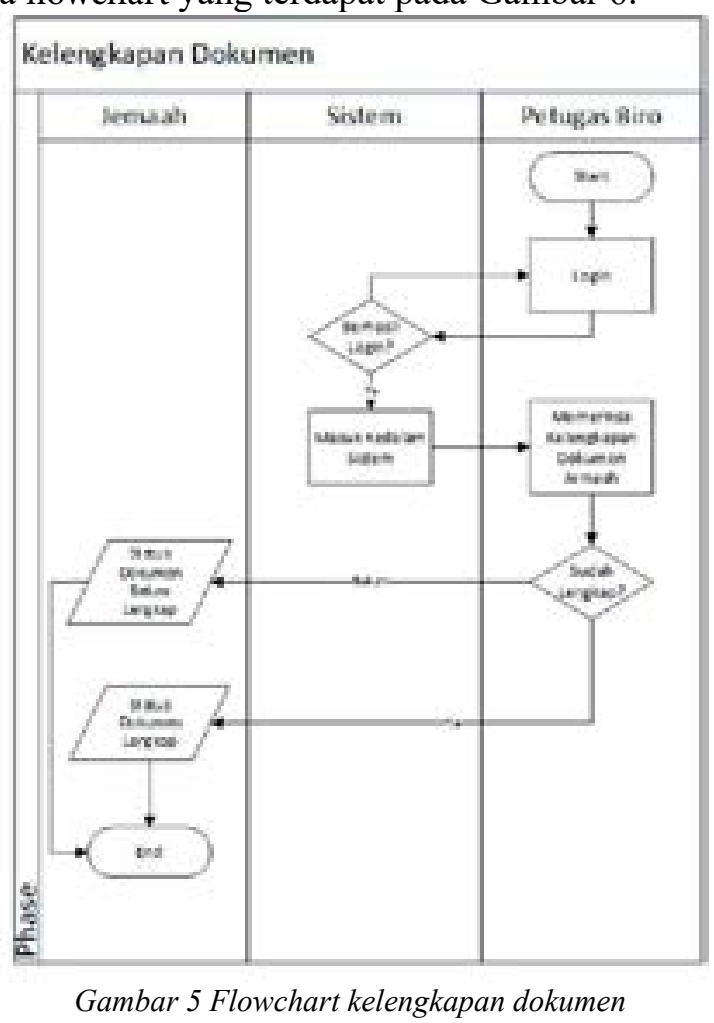

Penjelasan dari alur sistem baru pada proses pengecekan kelengkapan dokumen seperti yang digambarkan pada Gambar 5 yaitu: 1) Petugas biro login ke dalam website; 2) Setelah berhasil login, petugas biro memeriksa kelengkapan dokumen jemaah; 3) Apabila sudah lengkap, maka petugas akan 
mengupdate status dokumen jemaah menjadi Status Dokumen Lengkap; dan 4) Apabila belum lengkap, maka petugas akan mengupdate status dokumen jemaah menjadi Status Dokumen Belum Lengkap

\section{d. Status Keberangkatan}

Adapun aktifitas yang terdapat pada proses pergantian status keberangkatan dapat dilihat pada flowchart yang terdapat pada Gambar 7.

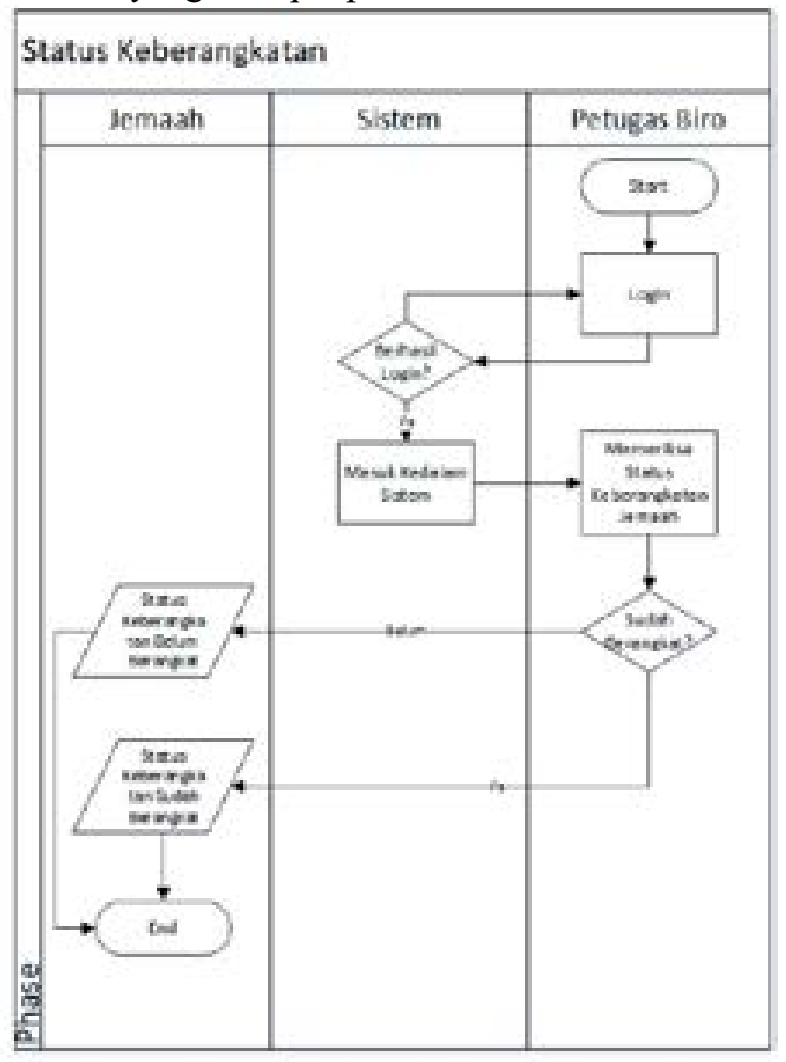

Gambar 6 Flowchart status keberangkatan

Penjelasan dari alur sistem baru pada proses pergantian status keberangkatan seperti yang digambarkan pada Gambar 6 yaitu: 1) Petugas biro login ke dalam website; 2) Setelah berhasil login, petugas biro memeriksa status keberangkatan jemaah; 3) Apabila sudah berangkat, maka petugas akan mengupdate status dokumen jemaah menjadi Sudah Berangkat; dan 4) Apabila belum berangkat, maka petugas akan mengupdate status dokumen jemaah menjadi Belum Berangkat.

\section{e. Ganti Password}

Adapun aktifitas yang terdapat pada proses penggantian password dapat dilihat pada flowchart yang terdapat pada Gambar 8 .

Penjelasan dari alur sistem baru pada proses penggantian password seperti yang digambarkan pada Gambar 7 yaitu: 1) Jemaah login ke dalam website; 2) Setelah berhasil login, melakukan pergantian password lama dengan password baru; 3) Untuk mengganti password lama dengan password baru, dibutuhkan password lama jemaah. Apabila

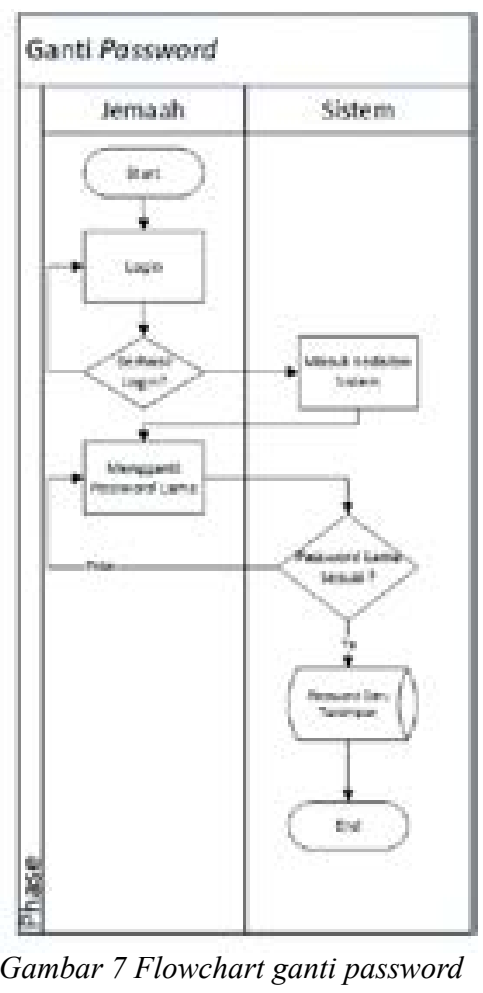

password lama tidak sesuai, maka jemaah harus kembali memasukkan password lama milik mereka sebelum mereka memasukkan password baru; dan 4) Apabila password lama sesuai dan telah memasukkan password baru, maka password baru milik jemaah akan tersimpan kedalam database.

\section{H. Perancangan Sistem}

Dalam melakukan perancangan sistem ini, Unified Modelling Language (UML) digunakan untuk perancangan database, dan perancangan antarmuka (user interface).

\section{Perancangan Unified Modelling Language}

Peneliti melakukan perancangan sistem dengan menggunakan Unified Modelling Language (UML). UML alat untuk memvisualisasikan dan mendokumentasikan hasil analisa dan desain yang berisi sintak dalam memodelkan sistem, juga merupakan satu kumpulan konvensi pemodelan yang digunakan untuk menggambarkan sebuah sistem software yang terkait dengan objek [7]. Diagram UML yang digunakan oleh peneliti terdiri dari use case diagram, activity diagram, dan sequence diagram.

\section{a. Use Case Diagram}

Use case diagram menggambarkan persyaratan fungsional sistem dalam hal kasus penggunaan. Ini adalah model fungsi sistem yang dimaksudkan (menggunakan kasus) dan lingkungannya (aktor) [8]. Berdasarkan sistem baru yang diajukan peneliti, maka peneliti membuat use case diagram sistem Pengecekan Status Dokumen Jemaah Umroh Pada 
PT. Solusi Balad Lumampah Berbasis Web yang diidentifikasikan berdasarkan aktor yaitu, jemaah, dan petugas biro. Kegiatan aktor pada sistem ini dapat dilihat pada use case diagram yang digambarkan pada Gambar 8.

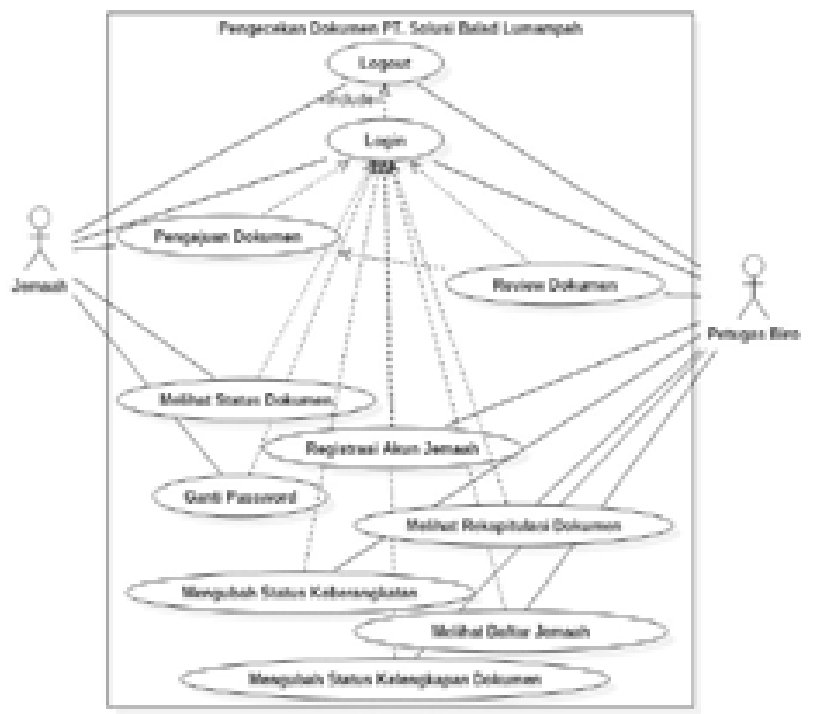

Gambar 8 Use Case diagram sistem

Penjelasan dari use case diagram tersebut dapat dilihat pada Tabel 2.

Tabel 2 Kebutuhan fungsional

\begin{tabular}{|c|c|}
\hline Use Case Name & Kebutuhan Fungsional Sistem \\
\hline Primary Actor & Jemaah \\
\hline Secondary Actor & Petugas Biro \\
\hline Description & $\begin{array}{l}\text { Use case ini menggambarkan } \\
\text { kegiatan yang dapat dilakukan ol } \\
\text { para actor pada rancangan sistem } \\
\text { baru Pengecekan Status Dokumer } \\
\text { Jemaah Umroh Pada PT. Solusi } \\
\text { Balad Lumampah Berbasis Web }\end{array}$ \\
\hline Pre-conditions & $\begin{array}{l}\text { Actor harus melakukan login } \\
\text { terlebih dahulu sebelum dapat } \\
\text { mengakses sistem }\end{array}$ \\
\hline Post-conditions & $\begin{array}{l}\text { Setiap data yang diinput kedalam } \\
\text { sistem akan tersimpan kedalam } \\
\text { database sesuai dengan apa yang } \\
\text { diinput } \\
\text { Kemudian sistem akan } \\
\text { menampilkan data yang diinput } \\
\text { kepada petugas biro }\end{array}$ \\
\hline Normal Scenario & $\begin{array}{l}\text { 1. Actor login ke dalam sistem. } \\
\text { 2. Setelah sistem memverifikasi } \\
\text { data login actor, sistem akan } \\
\text { menampilkan menu sesuai } \\
\text { dengan actor yang login ke } \\
\text { dalam sistem. } \\
\text { 3. Setiap actor hanya dapat } \\
\text { melakukan kegiatan yang ada } \\
\text { pada menu-menu yang tampil } \\
\text { setelah mereka login ke dalan } \\
\text { sistem. } \\
\text { 4. Setiap actor dapat logout unt } \\
\text { keluar dan mengakhiri kegiat: } \\
\text { dalam sistem tersebut. }\end{array}$ \\
\hline
\end{tabular}

\section{b. Activity Diagram}

Activity diagram adalah diagram yang menggambarkan aliran kerja dari sebuah sistem atau proses bisnis atau menu yang ada pada sebuah perangkat lunak. Activity diagram menggambarkan segala aktivitas yang terjadi didalam sebuah sistem, bukan apa yang dilakukan oleh aktor [9]. Berikut adalah activity diagram yang dibuat berdasarkan use case diagram yang terlah dimuat pada subbab sebelumnya. Penggambaran activity diagram pada sistem ini digambarkan berdasarkan user yang terlibat dalam pengoperasian sistem ini, yaitu jemaah, dan petugas biro. Peneliti tidak menyajikan semua activity diagram yang ada, melainkan activity diagram yang disajikan hanya beberapa, dan termasuk kedalam proses atau fitur-fitur utama yang terdapat pada sistem ini. Activity diagram yang ditampilkan pada jurnal penelitian ini, diantaranya activity diagram login, upload dokumen, registrasi akun jemaah, dan review.

\section{Activity Diagram Login}

Activity diagram login dibuat berdasarkan aktivitas login yang dapat dilakukan oleh kedua aktor, yaitu jemaah, dan petugas biro sebelum dapat menggunakan fitur-fitur yang terdapat pada sistem yang diusulkan oleh peneliti. Berikut adalah penggambaran dari activity diagram login yang dapat dilihat pada Gambar 9.

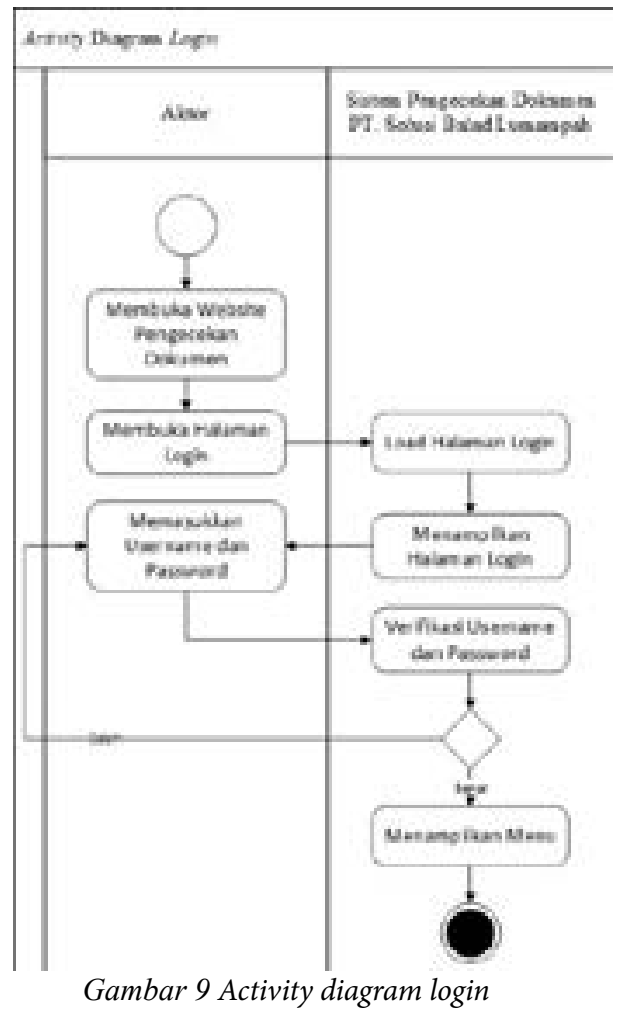

Pada Gambar 9 merupakan activity diagram yang menggambarkan proses login pada Sistem Pengecekan Dokumen PT. Solusi Balad Lumampah yang dapat dilakukan oleh jemaah dan admin. 


\section{Activity Diagram Upload Dokumen}

Activity diagram upload dokumen dibuat berdasarkan aktivitas login yang dapat dilakukan oleh jemaah setelah login kedalam sistem. Berikut adalah activity diagram upload dokumen yang dapat dilihat pada Gambar 10.

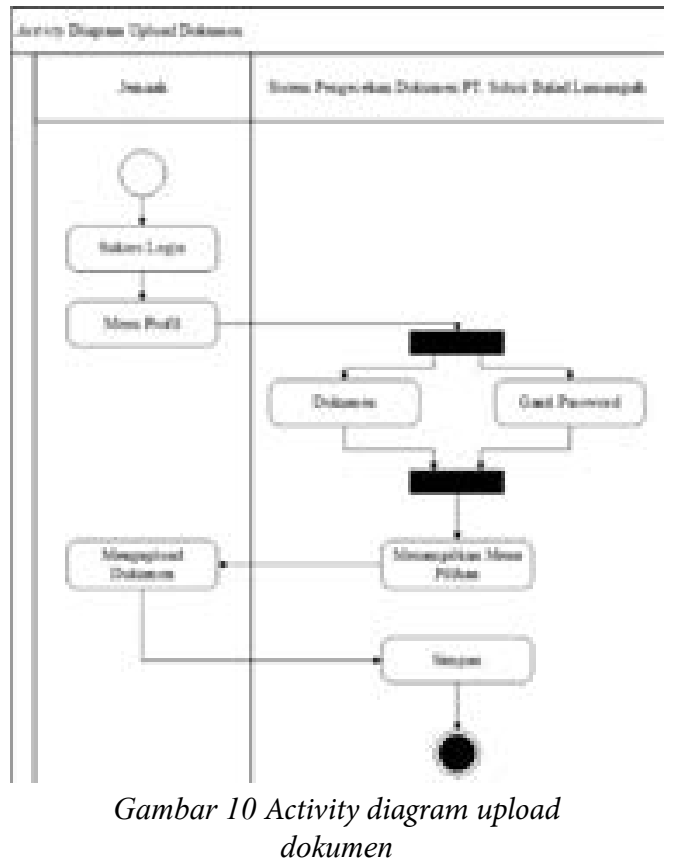

Gambar 10 merupakan activity diagram yang menggambarkan proses upload dokumen oleh jemaah. Saat jemaah memilih menu dokumen maka sistem akan menampilkan menu yang dipilih. Saat jemaah melakukan proses upload di menu dokumen, maka dokumen yang diupload akan disimpan kedalam basisdata.

\section{Activity Diagram Registrasi Akun Jemaah}

Activity diagram registrasi akun jemaah dibuat berdasarkan aktivitas login yang dapat dilakukan oleh petugas biro setelah login kedalam sistem. Berikut adalah activity diagram registrasi akun jemaah yang dapat dilihat pada Gambar 11.

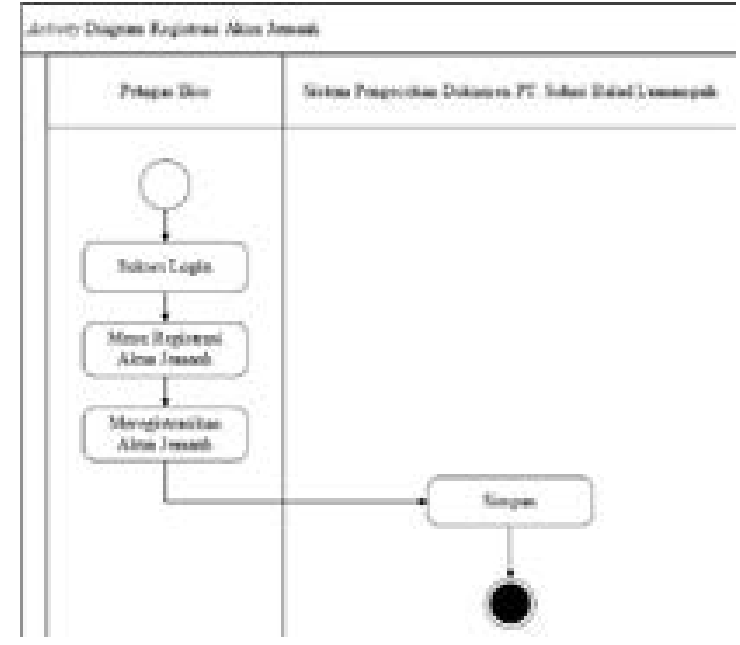

Gambar 11 Activity diagram registrasi akun jemaah
Gambar 11 merupakan activity diagram yang menggambarkan proses registrasi akun jemaah. Saat petugas biro selesai meregistrasikan akun jemaah, maka akun tersebut sudah dapat digunakan oleh jemaah.

\section{Activity Diagram Review}

Activity diagram review dibuat berdasarkan aktivitas login yang dapat dilakukan oleh petugas biro setelah login kedalam sistem. Berikut adalah activity diagram registrasi akun jemaah yang dapat dilihat pada Gambar 12.

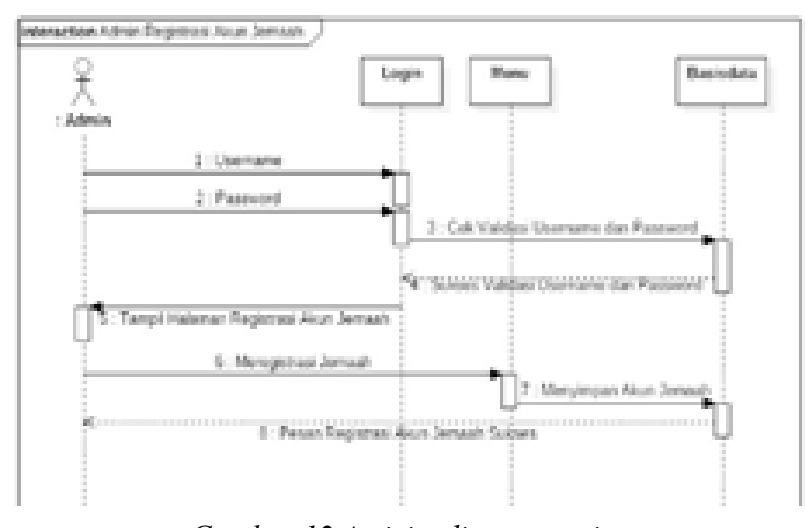

Gambar 12 Activity diagram review

\section{c. Sequence Diagram}

Sequence diagram menggambarkan kelakuan objek pada use case dengan mendeskripsikan waktu hidup objek dan message yang dikirimkan dan diterima antar objek. Oleh karena itu untuk menggambarkan diagram sekuen maka harus diketahui objek-objek yang terlibat dalam sebuah use case beserta metodemetode yang dimiliki [9].

Berikut adalah sequence diagram yang dibuat berdasarkan use case diagram yang telah dibuat. Penggambaran sequence diagram pada sistem ini berdasarkan user yang terlibat dalam pengoperasian sistem, yaitu jemaah, dan petugas biro. Sequence diagram yang ditampilkan pada jurnal penelitian ini hanyalah sequence diagram dari kegiatan utama yang terdapat pada fitur-fitur yang tersedia pada sistem ini, antara lain sequence diagram registrasi akun jemaah, dan sequence diagram upload dokumen.

1. Sequence Diagram Registrasi Akun Jemaah

Sequence diagram registrasi akun jemaah menggambarkan interaksi antar objek berdasarkan urutan yang terjadi pada saat registrasi akun jemaah. Sequence diagram untuk registrasi akun jemaah dapat dilihat pada Gambar 13.

2. Sequence Diagram Upload Dokumen

Sequence diagram upload dokumen menggambarkan interaksi objek berdasarkan urutan terjadi pada saat upload dokumen. Sequence diagram untuk upload dokumen dapat dilihat pada Gambar 14. 


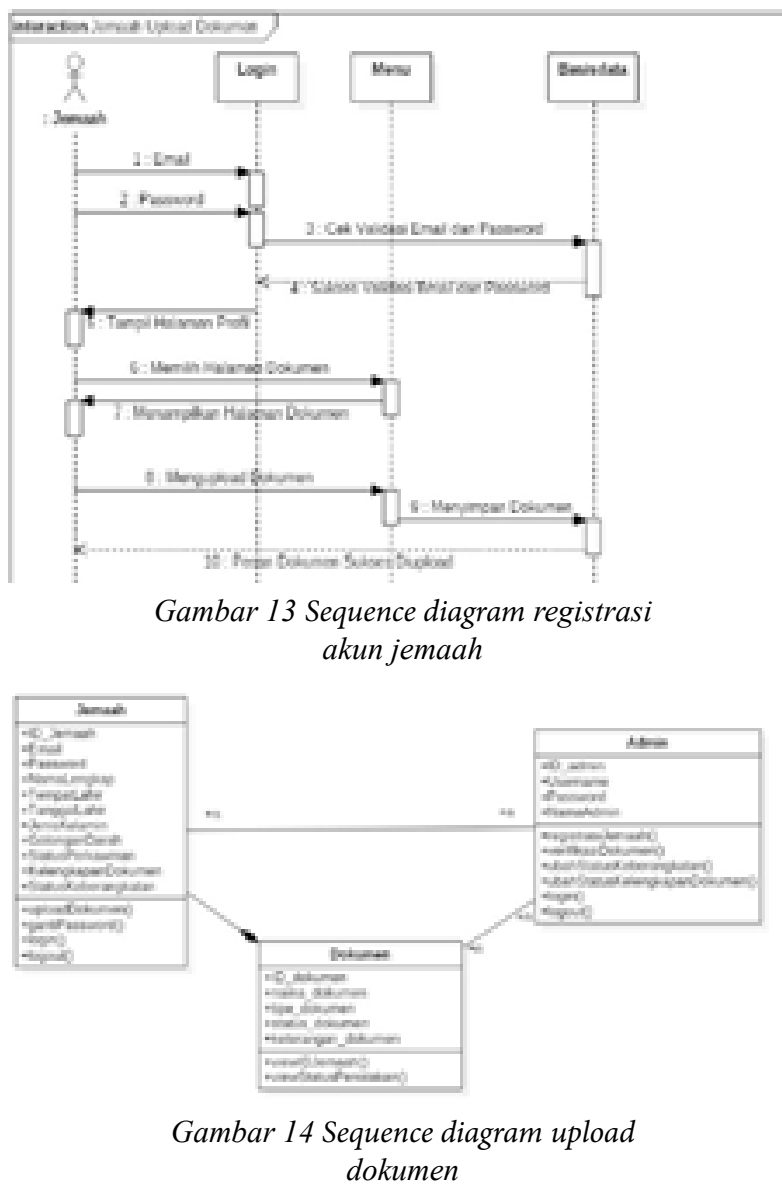

\section{d. Class Diagram}

Class diagram menggambarkan struktur sistem dari segi pendefinisian kelas-kelas yang akan dibuat untuk membangun sistem. Kelas memiliki atribut, dan metode atau operasi [9].

Berikut adalah class diagram yang dibuat untuk menggambarkan struktur sistem dari pendefinisian kelas-kelas yang dibuat untuk membagun sistem beserta operasi-operasi yang terdapat pada masingmasing kelas tersebut. Rancangan class diagram dapat dilihat pada Gambar 15.

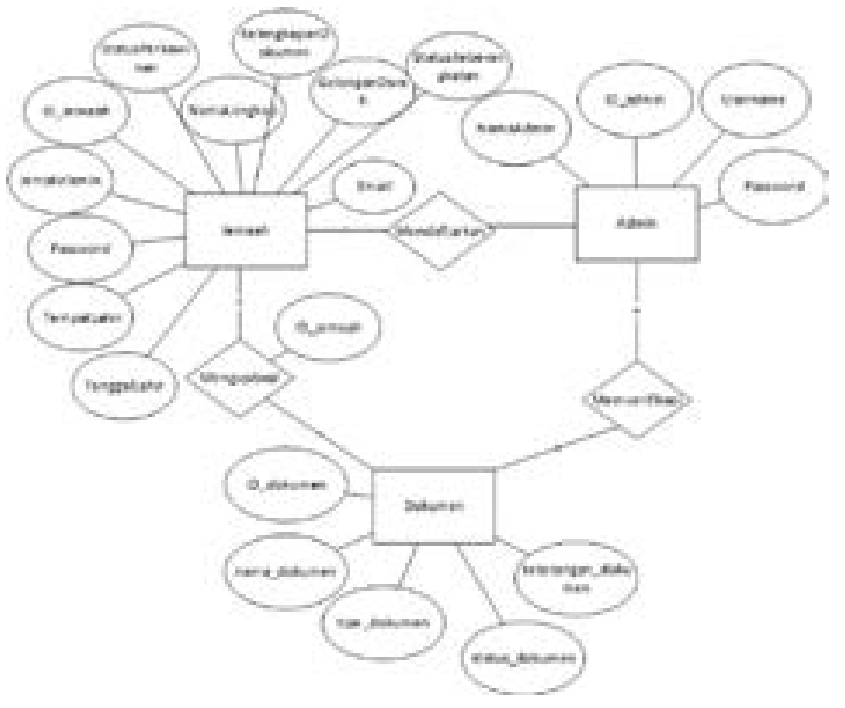

Gambar 15 Class diagram

\section{Perancangan Basisdata}

Perancangan basisdata bertujuan untuk menggambarkan relasi antar entititas. Perancangan basisdata yang dibuat oleh peneliti menggunakan Entity Relationship Diagram (ERD)

1. Entity Relationship Diagram

Entity Relationship Diagram (ERD) adalah jenis bagan alur yang mengilustrasikan bagaimana entitas seperti orang, objek, atau konsep saling berhubung satu sama lain dalam suatu sistem [7]. Sistem Pengecekan Status Dokumen Jemaah Umroh Pada PT. Solusi Balad Lumampah Berbasis Web memiliki empat entitas. Adapun empat entitas tersebut memiliki atribut yang ada pada Tabel 3, dan tergambar pada Gambar 16

Tabel 3 Daftar atribut dan entitas

\begin{tabular}{ll}
\hline \multicolumn{1}{c}{ Entitas } & \multicolumn{1}{c}{ Atribut } \\
\hline Jemaah & ID_jemaah, email, password, \\
& namaLengkap, TempatLahir, \\
& TanggalLahir, AlamatLengkap, \\
& JenisKelamin, StatusPerkawinan, \\
& GolonganDarah, \\
& kelengkapan_dokumen, \\
& status_penerbangan \\
\hline Dokumen & ID_dokumen, nama_dokumen, \\
& tipe_dokumen, status_dokumen, \\
& keterangan_dokumen, ID_jemaah \\
\hline Petugas & ID_admin, NamaAdmin, Username, \\
& Password \\
\hline
\end{tabular}
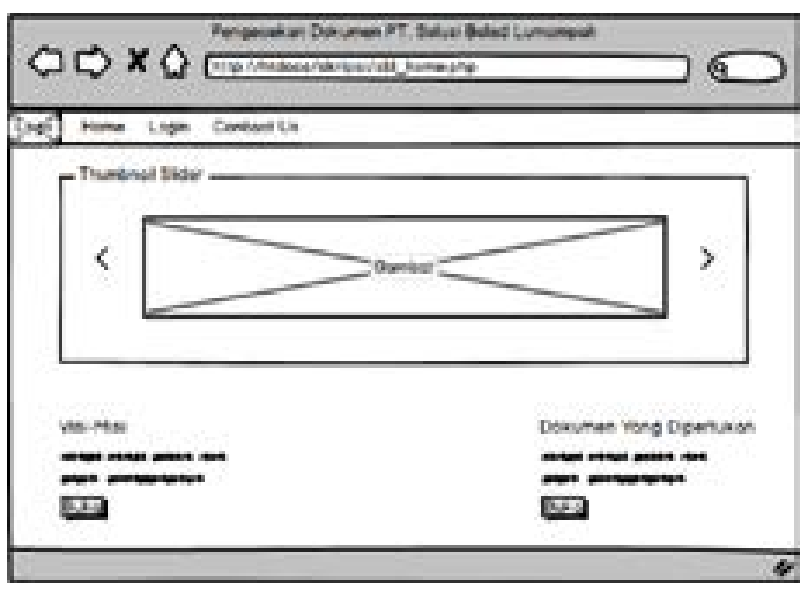

Gambar 16 Entity relationship diagram

J. Perancangan Antarmuka

Peneliti merancang tampilan antarmuka sistem yang terdiri dari halaman home, login, profil Jemaah, dokumen, registrasi akun Jemaah, dan review dengan menggunakan Balsamiq Mockup.

\section{Halaman Home}

Pada saat sistem digunakan maka yang tampil pertama kali adalah halaman home. Halaman home berisikan visi-misi perusahaan, dokumen yang dibutuhkan, dan memiliki thumbnail slider untuk 
gambar dari kegiatan Jemaah PT. Solusi Balad Lumampah. Rancangan tampilan halaman home yang digambarkan pada Gambar 17.

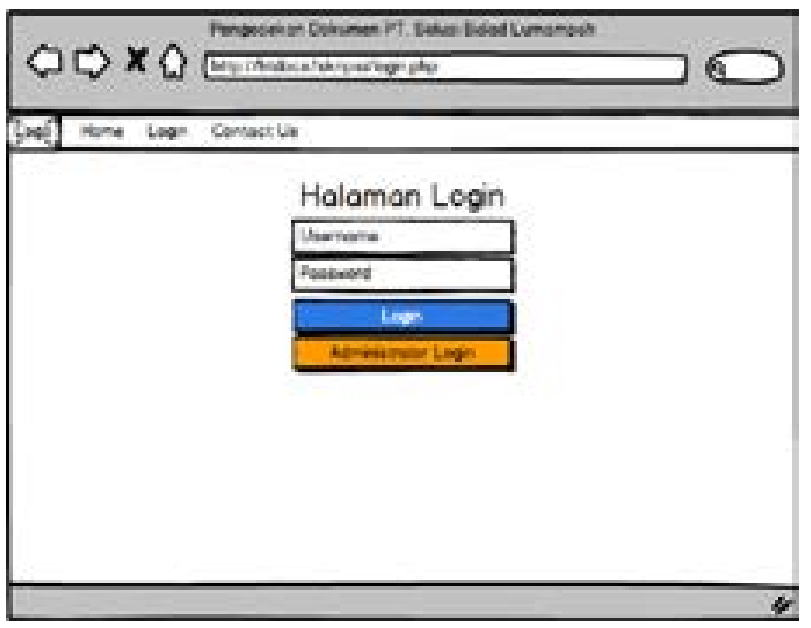

Gambar 17 Rancangan halaman home

Gambar 17 menggambarkan rancangan untuk halaman home. Pengguna dapat melihat visi-misi perusahaan, dan dokumen yang diperlukan dengan menekan button Buka yang tersedia.

\section{Halaman Login}

Halaman login merupakan halaman setelah home, form login yang tersedia dapat digunakan baik oleh Jemaah maupun petugas biro untuk masuk ke dalam sistem. Rancangan tampilan halaman home yang digambarkan pada Gambar 18.

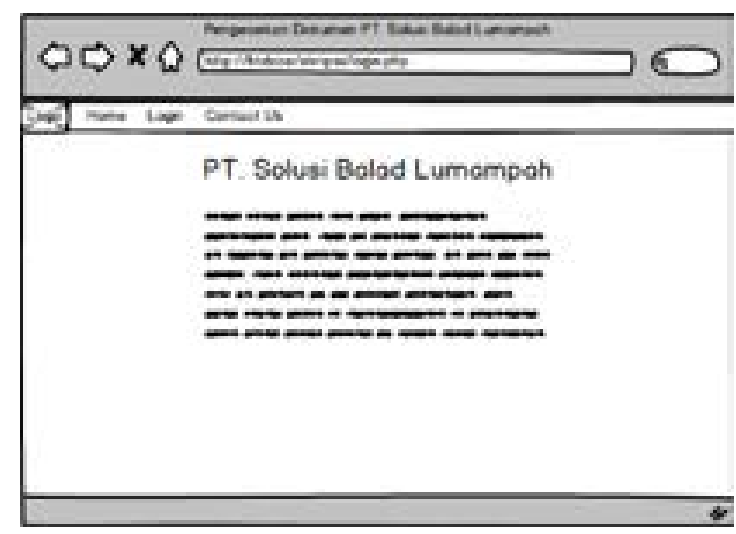

Gambar 18 Rancangan halaman login

Gambar 18 menggambarkan rancangan untuk halaman login. Pengguna akan diminta untuk memasukan username dan password yang dimiliki. Perbedaan login terdapat pada buttonlogin berwarna biru dengan oranye, dimana button login berwarna biru hanya dapat digunakan untuk Jemaah sedangkan button login berwarna oranye hanya dapat digunakan oleh petugas biro.

\section{Halaman Contact Us}

Halaman contact us merupakan halaman setelah login. Rancangan halaman contact us dapat dilihat pada Gambar 19.

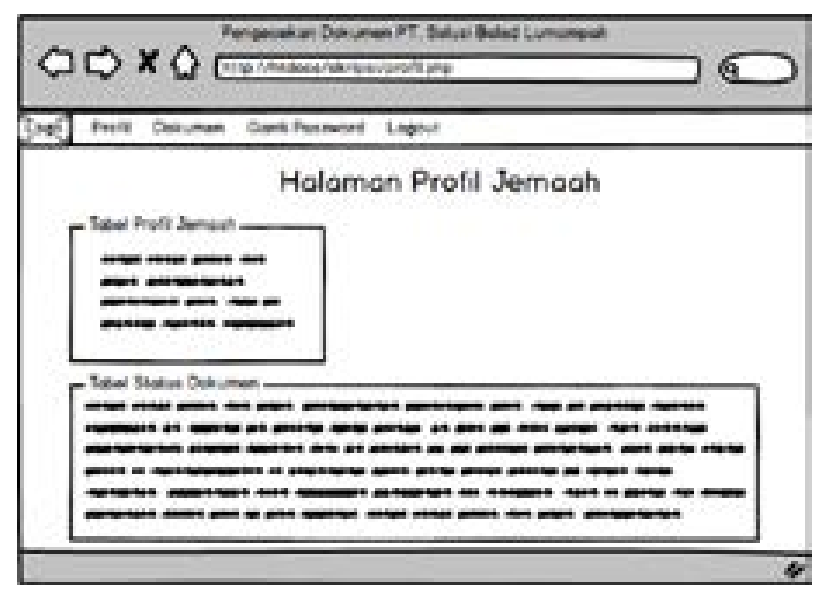

Gambar 19 Rancangan halaman contact Us

Gambar 19 menggambarkan rancangan untuk halaman contact us. Halaman contact us berisikan tentang informasi-informasi yang dapat digunakan untuk menghubungi pihak PT. Solusi Balad Lumampah.

4. Halaman Profil

Halaman profil merupakan halaman pertama yang terbuka ketika pengguna telah berhasil login kedalam sistem. Rancangan tampilan halaman profil dapat dilihat pada Gambar 20.

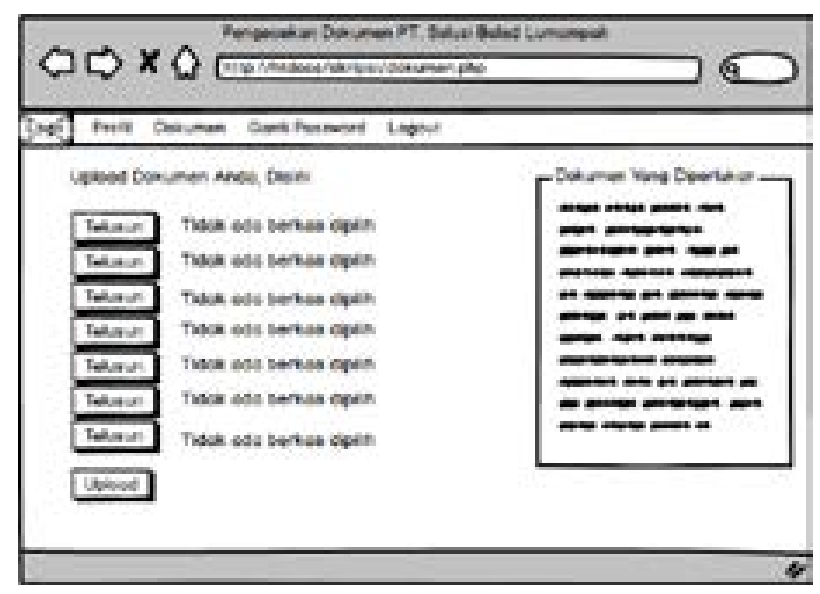

Gambar 20 Rancangan halaman profil

Gambar 20 menggambarkan rancangan untuk halaman profil. Halaman profil berisikan tentang

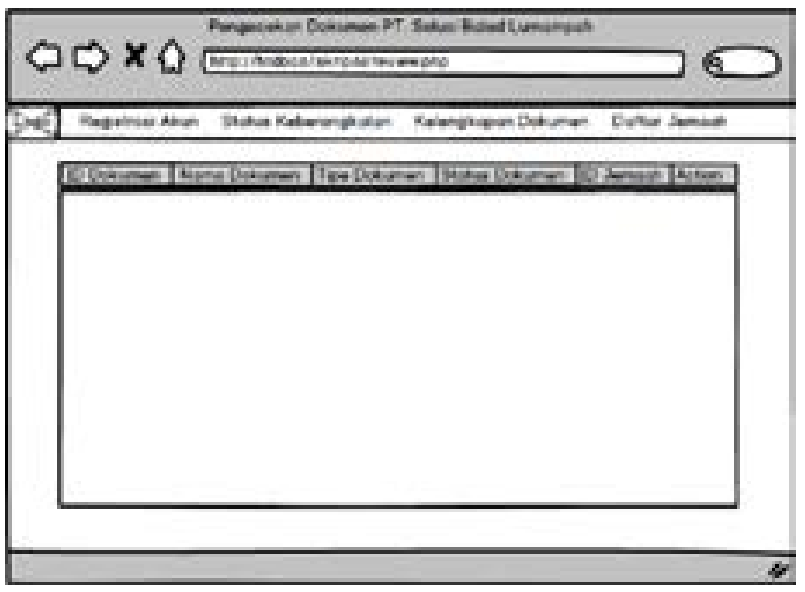

Gambar 21 Rancangan halaman dokumen 
informasi profil Jemaah, dan informasi tentang status dokumen yang sudah diupload oleh Jemaah.

\section{Halaman Dokumen}

Halaman dokumen merupakan halaman kedua yang dapat diakses oleh pengguna setelah berhasil login. Rancangan tampilan halaman dokumen dapat dilihat pada Gambar 21.

\section{Halaman Ganti Password}

Halaman ganti password merupakan halaman ketiga yang dapat diakses oleh jemaah. Rancangan tampilan halaman ganti password dapat dilihat pada Gambar 22.

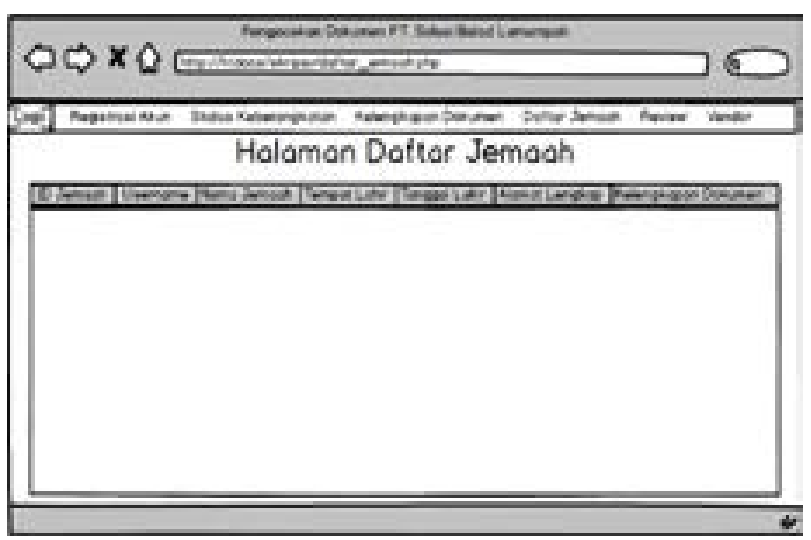

Gambar 22 Rancangan halaman ganti password

Halaman ganti password merupakan halaman ketiga yang dapat diakses oleh jemaah. Pada halaman ini terdapat tiga kolom yang harus diisi oleh jemaah yaitu, kolom password lama, password baru, dan konfirmasi password baru.

\section{Halaman Registrasi Akun Jemaah}

Halaman registrasi akun merupakan halaman awal yang ditampilkan ketika admin (dalam hal ini petugas biro) berhasil login kedalam sistem. Rancangan tampilan halaman registrasi dapat dilihat pada Gambar 23.

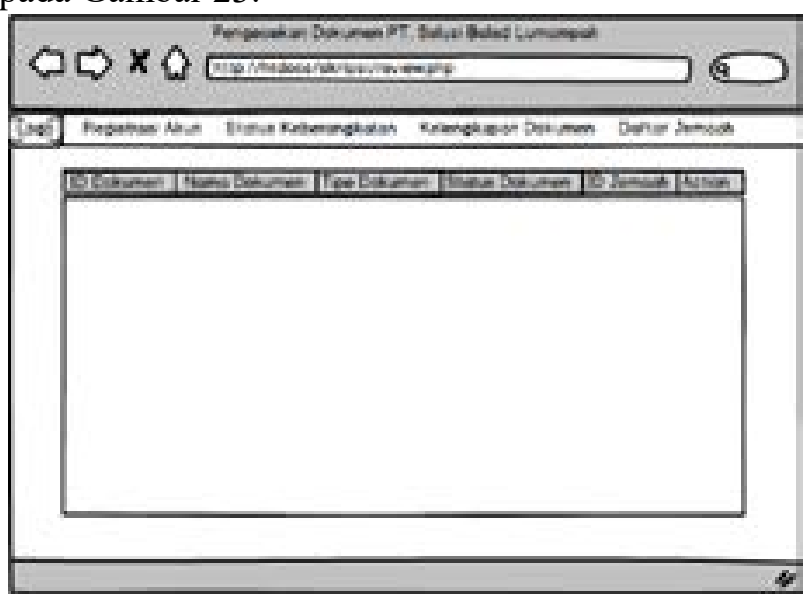

Gambar 23 Rancangan halaman registrasi akun jemaah

Halaman registrasi akun berisikan field-field yang dapat diisi oleh admin untuk dapat mendaftarkan akun untuk digunakan oleh Jemaah. Field-field tersebut haruslah diisi sesuai dengan kartu identitas yang dimiliki oleh Jemaah pada saat datang untuk membuat akun. Username dan password ditentukan oleh Jemaah itu sendiri.

\section{Halaman Review}

Halaman review merupakan halaman kedua yang dapat diakses oleh admin setelah sukses login kedalam sistem. Rancangan tampilan halaman review dapat dilihat pada Gambar 24.

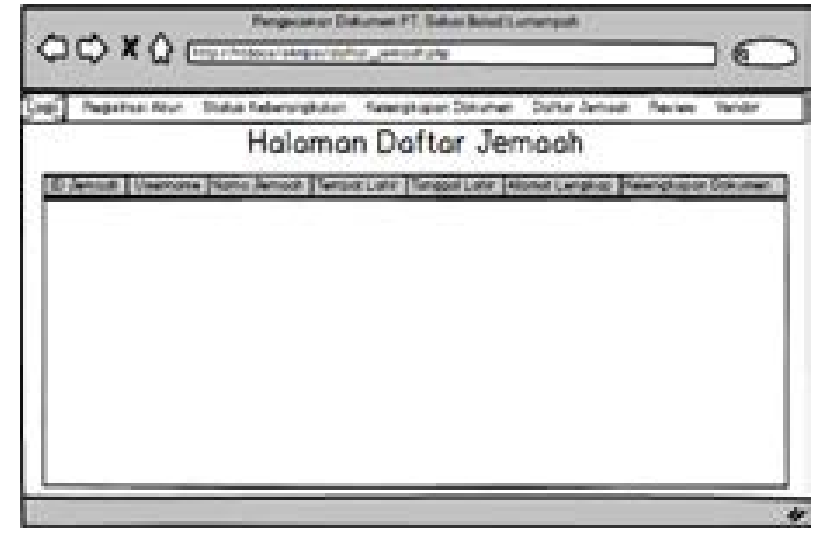

Gambar 24 Rancangan halaman review

Halaman review merupakan halaman yang berisikan tabel yang memuat isi dari folder dokumen jemaah yang tersimpan didalam komputer server. Pada halaman ini terdapat dokumen-dokumen milik jemaah yang telah diuploaddan tersimpan pada komputer server yang dapat dilihat oleh petugas biro, dan dapat dikonfirmasi oleh petugas biro bahwa dokumen tersebut benar atau salah.

\section{Halaman Daftar Jemaah}

Halaman daftar jemaah merupakan halaman keempat yang dapat diakses oleh admin setelah sukses login kedalam sistem. Rancangan tampilan halaman status keberangkatan dapat dilihat pada Gambar 25.

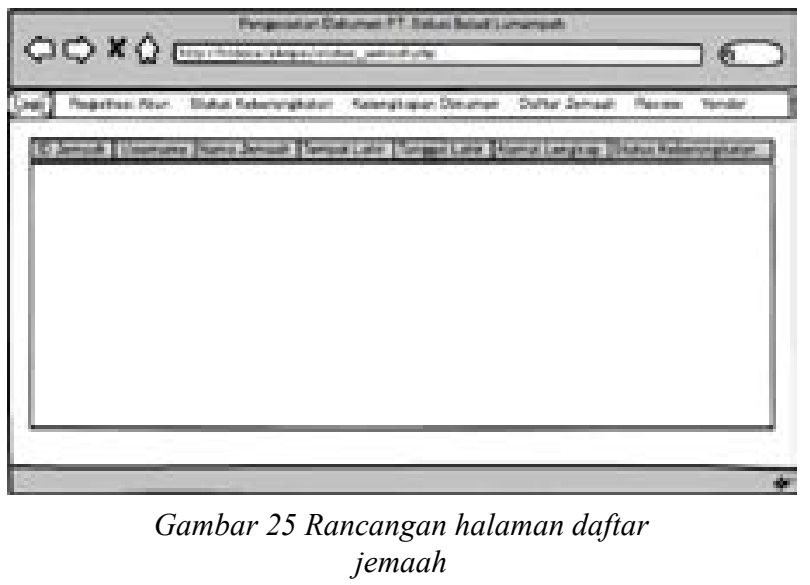

Halaman daftar jemaah merupakan halaman kelima yang dapat diakses oleh admin setelah sukses login kedalam sistem. Halaman ini memuat tabel yang berisikan data-data jemaah yang terdaftar. 


\section{Halaman Status Keberangkatan}

Halaman status keberangkatan merupakan halaman keenam yang dapat diakses oleh admin setelah sukses login kedalam sistem. Rancangan tampilan halaman status keberangkatan dapat dilihat pada Gambar 26.

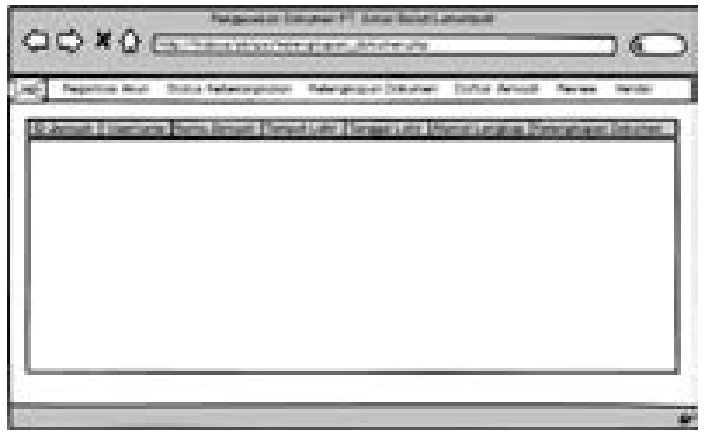

Gambar 26 Rancangan halaman status keberangkatan

Halaman status keberangkatan merupakan halaman keenam yang dapat diakses oleh admin setelah sukses login kedalam sistem. Halaman ini berisikan table yang memuat data-data jemaah beserta satu kolom yang memuat opsi untuk mengatur status keberangkatan jemaah.

\section{Halaman Kelengkapan Dokumen}

Halaman kelengkapan dokumen merupakan halaman ketujuh yang dapat diakses oleh admin setelah sukses login kedalam sistem.Rancangan tampilan halaman kelengkapan dokumen dapat dilihat pada Gambar 27.

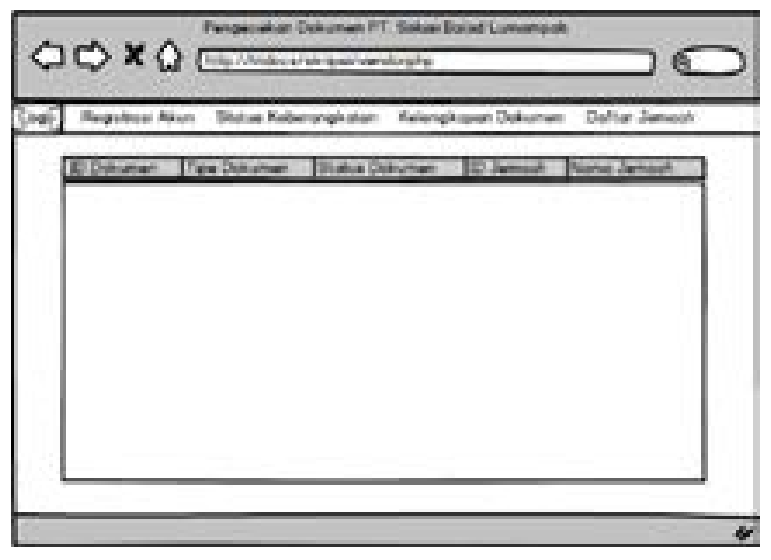

Gambar 27 Rancangan halaman

kelengkapan dokumen

Halaman kelengkapan dokumen merupakan halaman ketujuh yang dapat diakses oleh admin setelah sukses login kedalam sistem. Halaman ini berisikan table yang memuat data-data jemaah beserta satu kolom yang memuat opsi untuk mengatur status kelengkapan dokumen jemaah.

\section{Halaman Rekapitulasi Dokumen}

Halaman rekapitulasi dokumen merupakan halaman kedelapan yang dapat diakses oleh admin setelah sukses login kedalam sistem. Rancangan tampilan halaman rekapitulasi dokumen dapat dilihat pada Gambar 28.

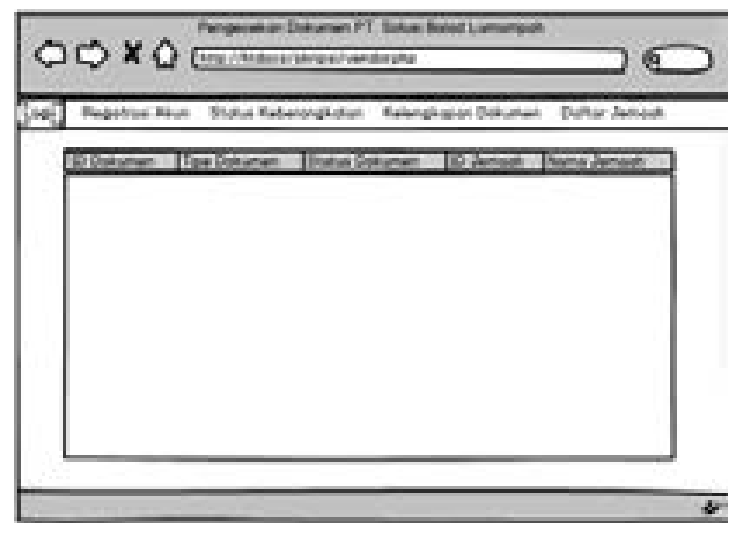

Gambar 28 Rancangan halaman rekapitulasi dokumen

Halaman rekapitulasi dokumen merupakan halaman kedelapan yang dapat diakses oleh admin setelah sukses login kedalam sistem. Halaman ini memuat tabel yang berisikan data-data dokumen jemaah.

\section{Halaman Keterangan Penolakan Dokumen}

Halaman keterangan penolakan dokumen merupakan halaman kesembilan yang dapat diakses oleh admin setelah sukses login kedalam sistem dan hanya dapat diakses pada saat-saat tertentu. Rancangan tampilan halaman rekapitulasi dokumen dapat dilihat pada Gambar 29.

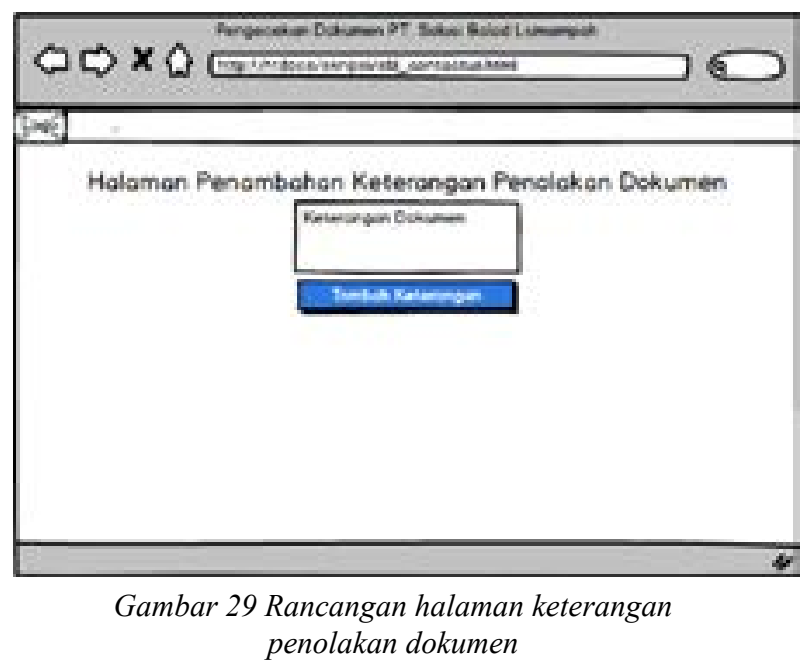

Halaman keterangan penolakan dokumen merupakan halaman kesembilan yang dapat diakses oleh admin setelah sukses login kedalam sistem dan hanya dapat diakses pada saat-saat tertentu. Halaman ini hanya akan tampil apabila pada di halaman review admin memilih "Tolak" dokumen. Halaman ini memuat sebuah form yang dapat diisi dengan alasan penolakan dokumen, dan sebuah button untuk menambah keterangan penolakan dokumen tersebut dan akan disimpan kedalam database. 


\section{K. Skenario Pengujian}

Pengujian akan dilakukan oleh peneliti sendiri dengan mengikuti skenario pengujian yang telah dibuat oleh peneliti, sesuai dengan apa yang telah peneliti lakukan untuk membangun sistem Pengecekan Status Dokumen Berbasis Web Pada PT. Solusi Balad Lumampah. Skenario pengujian dapat dilihat pada Tabel 4.

Tabel 4 Skenario pengujian

\begin{tabular}{|c|c|}
\hline Kelas Uji & Butir Uji \\
\hline Halaman Home & $\begin{array}{l}\text { Menampilkan informasi visi-misi } \\
\text { perusahaan, persyaratan dokumen, dan } \\
\text { thumbnail slider gambar }\end{array}$ \\
\hline Halaman Login & Menampilkan form login \\
\hline $\begin{array}{l}\text { Halaman Contact } \\
\text { Us }\end{array}$ & $\begin{array}{l}\text { Menampilkan informasi seputar } \\
\text { perusahaan }\end{array}$ \\
\hline Halaman Profil & $\begin{array}{l}\text { Menampilkan informasi seputar profil } \\
\text { jemaah dan status dokumen }\end{array}$ \\
\hline Halaman Dokumen & $\begin{array}{l}\text { Menampilkan form upload dokumen } \\
\text { dan informasi dokumen yang } \\
\text { dibutuhkan }\end{array}$ \\
\hline $\begin{array}{l}\text { Halaman Ganti } \\
\text { Password }\end{array}$ & $\begin{array}{l}\text { Menampilkan tiga form yang } \\
\text { digunakan untuk mengganti password } \\
\text { lama jemaah dengan yang baru }\end{array}$ \\
\hline $\begin{array}{l}\text { Halaman Registrasi } \\
\text { Akun Jemaah }\end{array}$ & $\begin{array}{l}\text { Menampilkan beberapa form yang } \\
\text { digunakan untuk meregistrasikan akun } \\
\text { jemaah }\end{array}$ \\
\hline Halaman Review & $\begin{array}{l}\text { Menampilkan tabel yang memuat } \\
\text { informasi tentang dokumen jemaah } \\
\text { yang telah diupload }\end{array}$ \\
\hline $\begin{array}{l}\text { Halaman Status } \\
\text { Keberangkatan }\end{array}$ & $\begin{array}{l}\text { Menampilkan tabel yang memuat } \\
\text { informasi tentang jemaah beserta } \\
\text { status keberangkatan }\end{array}$ \\
\hline $\begin{array}{l}\text { Halaman } \\
\text { Kelengkapan } \\
\text { Dokumen }\end{array}$ & $\begin{array}{l}\text { Menampilkan table yang memuat } \\
\text { informasi tentang jemaah beserta } \\
\text { status dokumennya }\end{array}$ \\
\hline $\begin{array}{l}\text { Halaman Daftar } \\
\text { Jemaah }\end{array}$ & $\begin{array}{l}\text { Menampilkan tabel yang memuat } \\
\text { informasi tentang jemaah beserta } \\
\text { status keberangkatan dan kelengkapan } \\
\text { dokumen }\end{array}$ \\
\hline $\begin{array}{l}\text { Halaman } \\
\text { Rekapitulasi } \\
\text { Dokumen }\end{array}$ & $\begin{array}{l}\text { Menampilkan tabel informasi tentang } \\
\text { dokumen yang sudah diupload }\end{array}$ \\
\hline $\begin{array}{l}\text { Halaman } \\
\text { Keterangan } \\
\text { Penolakan } \\
\text { Dokumen }\end{array}$ & $\begin{array}{l}\text { Menampilkan form yang dapat diisi } \\
\text { dengan alasan penolakan dokumen, } \\
\text { dan sebuah button untuk menambah } \\
\text { keterangan penolakan dokumen } \\
\text { tersebut }\end{array}$ \\
\hline
\end{tabular}

\section{Hasil Pembangunan Sistem}

Tahap ini merupakan hasil dari pembangunan Sistem Pengecekan Dokumen Berbasis Web Pada PT. Solusi Balad Lumampah yang terdiri dari tampilan halaman home, halaman login, halaman contact us, halaman profil, halaman dokumen, halaman ganti password, halaman registrasi akun jemaah, halaman status keberangkatan, halaman status kelengkapan dokumen, halaman daftar jemaah, halaman review, halaman rekapitulasi dokumen jemaah, dan halaman keterangan penolakan dokumen.

\section{Halaman Home}

Pada halaman home, userakan menemui tampilan slider thumbnail, dan button untuk menampilkan visi-misi perusahaan, dan dokumen yang diperlukan untuk memenuhi syarat perjalanan haji atau umroh. Tampilan halaman home dapat dilihat pada Gambar 30 .

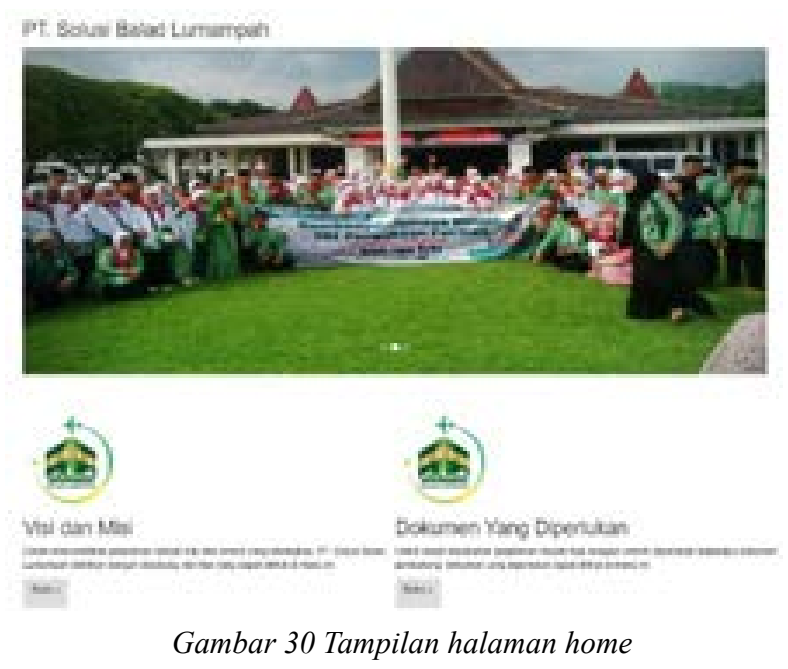

\section{Halaman Login}

Padahalamanlogin, user dapat memasukkan username, dan password agar dapat masuk kedalam sistem. Terdapat dua buttonlogin, yang pertama login berwarna biru digunakan untuk login jemaah, sedangkan administrator login digunakan untuk login admin. Tampilan halaman login dapat dilihat pada Gambar 31.

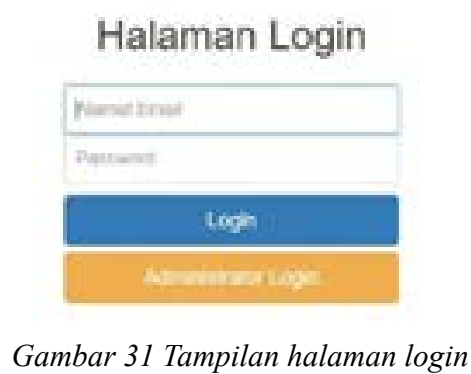

\section{Halaman Contact Us}

Pada halaman contact us, user dapat melihat informasi, dan kontak tentang perusahaan. Tampilan halaman login dapat dilihat pada Gambar 32.

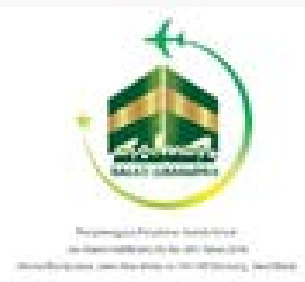

Gambar 32 Tampilan halaman contact us

\section{Halaman Profil}

Halaman profil adalah halaman pertama yang ditemui oleh jemaah setelah berhasil login kedalam sistem. Halaman ini berisikan dua tabel memuat profil tentang jemaah tersebut, dan status dokumen 
yang telah diupload. Tampilan halaman profil dapat dilihat pada Gambar 33.

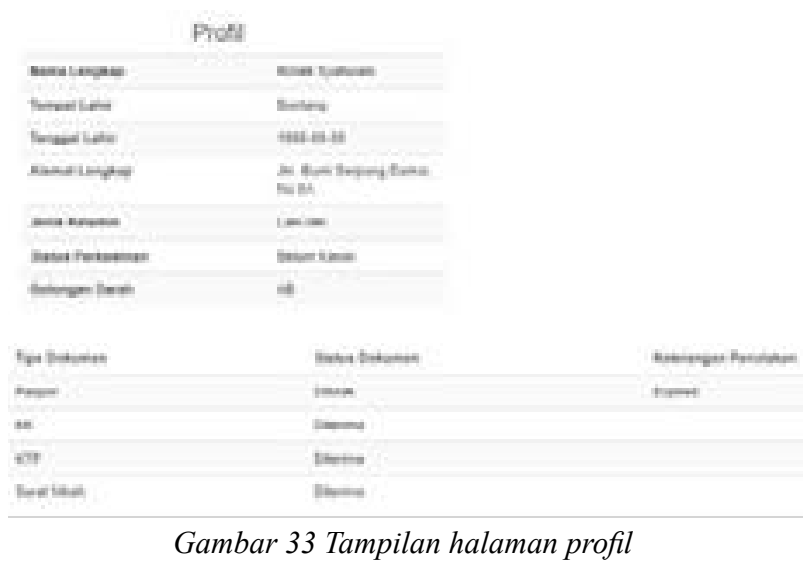

\section{Halaman Dokumen}

Halaman Dokumen merupakan halaman kedua yang dapat diakses oleh jemaah setelah berhasil login kedalam sistem. Pada halaman ini userakan menemui tujuh form upload dokumen, dan terdapat daftar dokumen yang dibutuhkan oleh user untuk memenuhi persyaratan perjalanan ibadah haji, atau umroh. Tampilan halaman dokumen dapat dilihat pada Gambar 34.

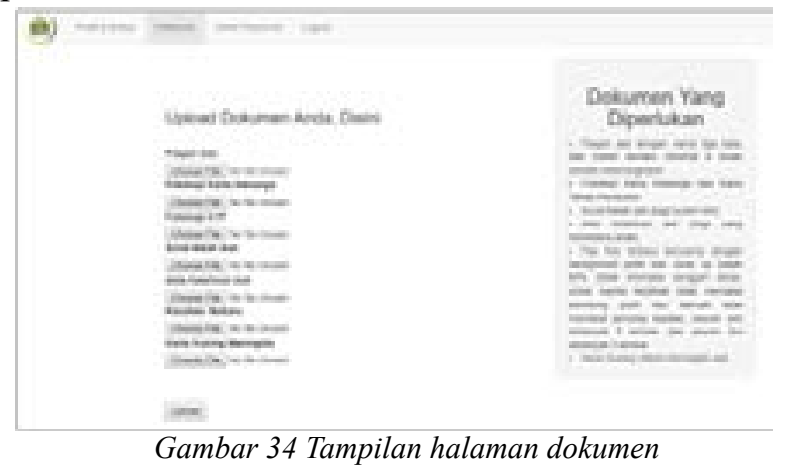

\section{Halaman Ganti Password}

Halaman ganti password merupakan halaman ketiga yang dapat diakses oleh jemaah setelah berhasil login kedalam sistem. Pada halaman ganti password terdapat tiga form input yang digunakan untuk mengganti password akun jemaah. Ketiga form input tersebut adalah form password lama, form password baru, dan form konfirmasi password baru. Dapat dilihat pada Gambar 35.

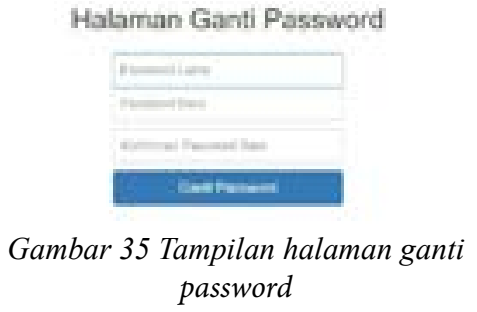

\section{Halaman Registrasi Akun Jemaah}

Halaman registrasi akun jemaah adalah halaman pertama yang dapat diakses oleh admin setelah sukses login kedalam sistem. Halaman ini menampilkan sebuah form yang terdiri dari beberapa inputan yang digunakan untuk meregistrasikan akun jemaah. Tampilan halaman registrasi akun jemaah dapat dilihat pada Gambar 36.

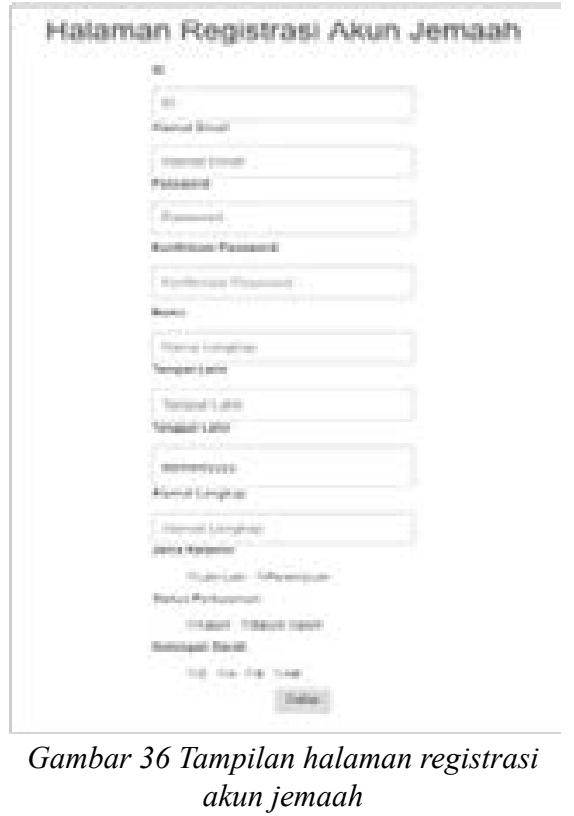

\section{Halaman Status Keberangkatan}

Halaman status keberangkatan adalah halaman kedua yang dapat diakses oleh admin setelah sukses login kedalam sistem. Halaman ini menampilkan sebuah tabel yang memuat data dari para jemaah yang terdaftar. Terdapat satu kolom bernama Status Keberangkatan yang memuat button yang digunakan untuk mengubah status keberangkatan jemaah. Tampilan halaman status keberangkatan dapat dilihat pada Gambar 37.

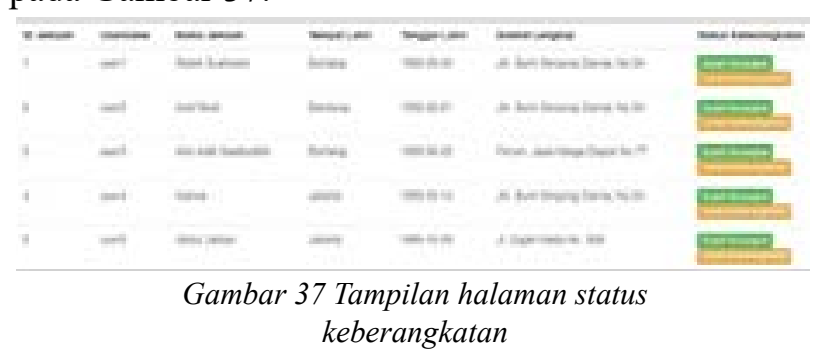

\section{Halaman Kelengkapan Dokumen}

Halaman kelengkapan dokumen adalah halaman ketiga yang dapat diakses oleh admin setelah sukses login kedalam sistem. Halaman ini menampilkan sebuah tabel yang memuat data dari para jemaah yang terdaftar. Terdapat satu kolom bernama Kelengkapan

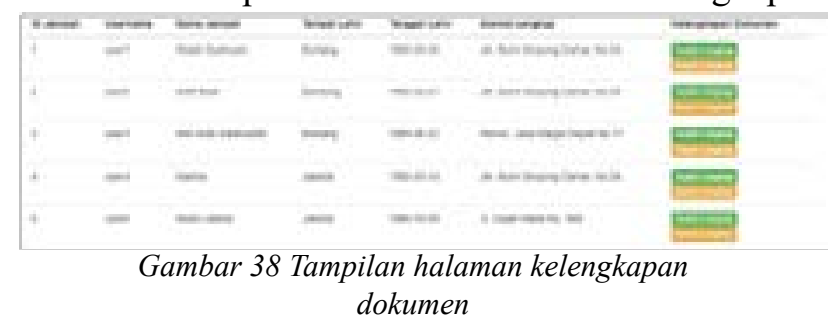


Dokumen yang memuat button yang digunakan untuk mengubah status kelengkapan dokumen jemaah. Tampilan halaman status keberangkatan dapat dilihat pada Gambar 38.

\section{Halaman Daftar Jemaah}

Halaman daftar jemaah adalah halaman keempat yang dapat diakses oleh admin setelah sukses login kedalam sistem. Halaman ini menampilkan sebuah tabel yang memuat data jemaah. Di dalam tabel tersebut terdapat dua kolom yang masingmasingkolom tersebut memuat status keberangkatan, dan status kelengkapan dokumen jemaah. Tampilan halaman daftar jemaah dapat dilihat pada Gambar 39.

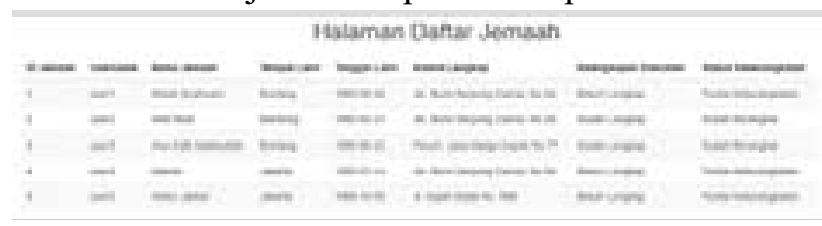

Gambar 39 Tampilan halaman daftar jemaah

\section{Halaman Review}

Halaman review adalah halaman kelima yang dapat diakses oleh admin setelah sukses login kedalam sistem. Halaman ini menampilkan sebuah tabel yang memuat dokumen-dokumen yang telah diupload oleh jemaah. Terdapat satu kolom yang berisikan button untuk mengubah status dokumen jemaah, menjadi diterima, atau ditolak. Tampilan halaman review dapat dilihat pada Gambar 40.

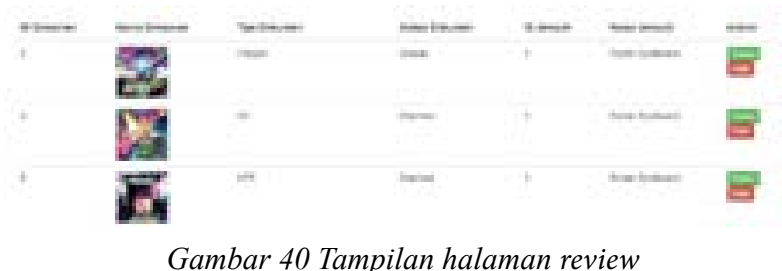

\section{Halaman Rekapitulasi Dokumen}

Halaman rekapitulasi dokumen merupakan halaman kedelapan yang dapat diakses oleh admin setelah sukses login kedalam sistem.Halaman ini menampilkan sebuah tabel yang memuat data dokumen jemaah. Tampilan halaman rekapitulasi dokumen dapat dilihat pada Gambar 41.

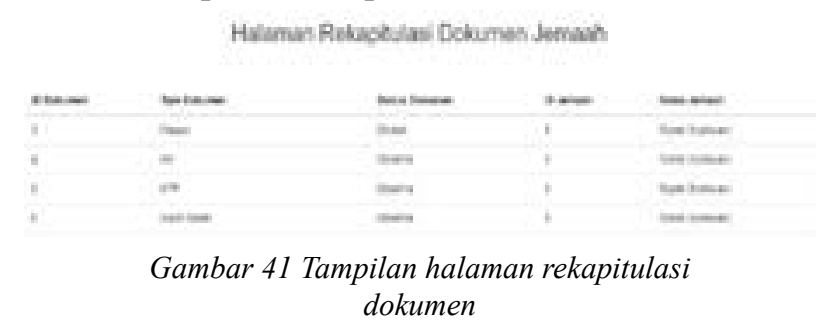

12. Halaman Keterangan Penolakan Dokumen

Halaman keterangan penolakan dokumen merupakan halaman kesembilan yang dapat diakses oleh admin setelah sukses login kedalam sistem dan hanya dapat diakses pada saat-saat tertentu. Tampilan halaman rekapitulasi dokumen dapat dilihat pada Gambar 42.

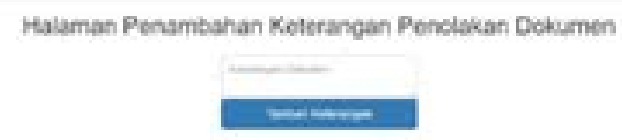

Gambar 42 Tampilan halaman keterangan penolakan dokumen

\section{SIMPULAN}

Penelitian ini menghasilkan Sistem Pengecekan Status Dokumen Berbasis Web Pada PT. Solusi Balad Lumampah yang dapat membantu jemaah dalam mengajukan berkas, dan mengetahui status dokumen milik mereka sehingga tidak perlu untuk mendatangi kantor biro apabila memiliki dokumen yang salah atau tidak sesuai dengan persyaratan. Sistem Pengecekan Status Dokumen Berbasis Web ini juga dapat membantu petugas biro dalam melakukan pengecekan atau review dokumen milik jemaah, memberitahu status dokumen milik jemaah, dan mengurangi penumpukan dokumen fisik yang terjadi pada kantor biro.

\section{DAFTAR RUJUKAN}

[1] Solusi Balad Lumampah, "Solusi Balad Lumampah," Desember 2015. [Online]. Available: www.sbl.co.id. [Accessed 20 Februari 2018].

[2] Kementerian Agama, "Kementerian Agama RI - Informasi Haji," 2016. [Online]. Available: https://haji.kemenag. go.id/v3/regulasi/undang-undang/uu-13. [Accessed 28 Juni 2018].

[3] Kementerian Agama, "Kementerian Agama RI - Informasi Haji,” 2018. [Online]. Available: https://www.haji. kemenag.go.id/v3/content/pma-nomor-8-tahun-2018tentang-penyelenggaraan-perjalanan-ibadah-umrah. [Accessed 28 Juni 2018].

[4] R. S. Pressman, Software Engineering: A Practitioner's Approach, 2010, New York, McGraw-Hill, New York: McGraw-Hill, 2010.

[5] F. Susanto., Siswanto., D. Saputra, "Perancangan Sistem Tracking Report Process Production," Perancangan Sistem Tracking Report Process Production Pada PT. Indotaichen Textile Industry, vol. 3, no. 30, pp. 279284, 2014.

[6] M. Y. R. Siregar., Fajrillah, "PENGEMBANGAN SISTEM PENGELOLAAN PUBLIKASI DOKUMEN,” Jurnal 
Ilmiah Informatika, vol. 1, no. 1, p. 24, 2016.

[7] Haviluddin, "Memahami Penggunaan UML (Unified Modelling Language)," Jurnal Informatika Mulawarman, vol. 6, no. 1, p. 1, 08 Juli 2011.

[8] Visual-Paradigm, "What is Unified Modeling Language?," 29 Juli 2016. [Online]. Available: https://www.visualparadigm.com/guide/uml-unified-modeling-language/ what-is-uml/. [Accessed 25 Juli 2018].
[9] M. Shalahuddin., Rosa A. S., Rekayasa Perangkat Lunak Terstruktur dan Berorientasi Objek, Bandung: Informatika, 2015.

[10] Lucid Software Inc., "What is an Entity Relationship Diagram,” 27 Desember 2016. [Online]. Available: https://www.lucidchart.com/pages/er-diagrams. [Accessed 25 Juli 2018]. 